Isis Mozetic

\title{
CONSERVAÇÃO DE CÉLULAS LINFOIDES INATAS DO TIPO \\ 2 E AUMENTO DE LINFÓCITOS B AUTORREATIVOS DO CENTRO GERMINATIVO EM PACIENTES COM LÚPUS ATIVO
}

Dissertação apresentada à Sociedade Beneficente Israelita Brasileira Albert Einstein para obtenção do título de Mestre em Ciências da Saúde.

São Paulo 


\section{Isis Mozetic}

\section{CONSERVAÇÃO DE CÉLULAS LINFOIDES INATAS DO TIPO \\ 2 E AUMENTO DE LINFÓCITOS B AUTORREATIVOS DO CENTRO GERMINATIVO EM PACIENTES COM LÚPUS ATIVO}

Dissertação apresentada à Sociedade Beneficente Israelita Brasileira Albert Einstein para obtenção do título de Mestre em Ciências da Saúde.

Orientadora: Profa. Dra. Karina Inácio Ladislau de Carvalho 
M939b

Mozetic, Isis

Conservação de células linfoides inatas do tipo 2 e aumento de linfócitos B autorreativos do centro germinativo em pacientes com lúpus ativo / Isis Mozetic. -- São Paulo, 2018.

xiii; 52 f., il.

Dissertação (Mestrado) - Sociedade Beneficente Israelita Brasileira Albert Einstein, Instituto de Ensino e Pesquisa Albert Einstein, Programa de Pós-Graduação em Ciências da Saúde.

Título em inglês: Low expression of type 2 innate lymphoid cells and increase of autoreactive germinal center $B$ lymphocytes in patients with active lupus.

1. Lúpus eritematoso sistêmico. 2. Linfócitos B. 3. Células linfoides inatas tipo 2. 4. Linfócitos T. 5. Imunidade celular.

NLM - WD 380

Elaborado pelo Sistema Einstein Integrado de Bibliotecas 
SOCIEDADE BENEFICENTE ISRAELITA BRASILEIRA ALBERT EINSTEIN

Coordenador do Curso de Pós-Graduação: Prof. Dr. Luiz Vicente Rizzo 
Isis Mozetic

\section{CONSERVAÇÃO DE CÉLULAS LINFOIDES INATAS DO TIPO 2 E AUMENTO DE LINFÓCITOS B AUTORREATIVOS DO CENTRO GERMINATIVO EM PACIENTES COM LÚPUS ATIVO}

Presidente da banca: Profa. Dra. Karina Inácio Ladislau de Carvalho

BANCA EXAMINADORA

Membros titulares:

Profa. Dra. Erika Bevilaqua Rangel

Profa. Dra. Ana Maria Moro

Dr. Nilton Salles Rosa Neto

Membros suplentes:

Prof. Dr. Alexandre de Castro Keller

Prof. Dr. Thiago Pinheiro Arrais Aloia

Aprovada em: 28/05/2018. 


\section{Dedicatória}

Dedico este trabalho à minha família e aos meus amigos que me incentivaram desde o início em todas as minhas decisões, e foram o meu suporte nos momentos difíceis. 


\section{Agradecimentos}

À minha orientadora Dra. Karina Inácio Ladislau de Carvalho, pela orientação, ensinamentos, pelas oportunidades de experiência prática e sua dedicação como orientadora, que sempre esteve presente nos acompanhando e nos ajudando.

Aos meus colegas do laboratório e equipe técnica, que além do incentivo e da ajuda prestada, demonstraram que é possível conviver em grupo e que isso é muito enriquecedor a todos os alunos. Em especial ao meu grupo: Ana Eduarda Zulim de Carvalho, Bruna Mariana Alves da Silva, Caroline Mitiká Watanabe, Claudia Concer Viero Nora, Eliane Conti Mairena, Giovana Alonso, Karen Reis Alencar Oliveira, Letícia D’Argenio Garcia, Reginaldo Keller Fernandes, Santiago Andrés Vilella Arias.

A todos os voluntários que gentilmente aceitaram participar do nosso trabalho, pois não seria possível realizar este trabalho sem a colaboração de todos eles.

À equipe do Hospital Israelita Albert Einstein, Dr. Cristóvão Mangueira e Dra. Eliane Aparecida Rosseto, e toda a equipe de Imunologia do Laboratório Clínico do HIAE, pelo apoio técnico durante a realização de todos os exames laboratoriais deste trabalho.

À instituição parceira desse projeto, Santa Casa de Misericórdia de São Paulo, Dra. Branca Dias Batista de Souza, Dra. Juliana Miranda de Lucena Valim e aos Residentes do Ambulatório de Reumatologia, pela dedicação e hospitalidade oferecidas durante o recrutamento de voluntários para este trabalho.

Agradeço também ao Programa de Pós-Graduação em Ciências da Saúde, que busca sempre oferecer o melhor conteúdo, visando formar Mestres e Doutores com o diferencial da visão holística, em que a ciência básica e a prática clínica caminham juntas. 


\section{Sumário}

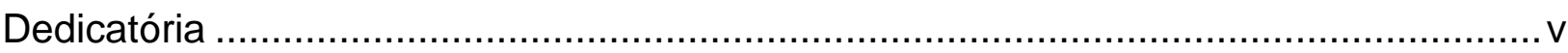

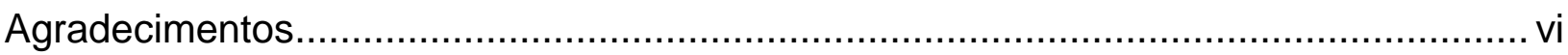

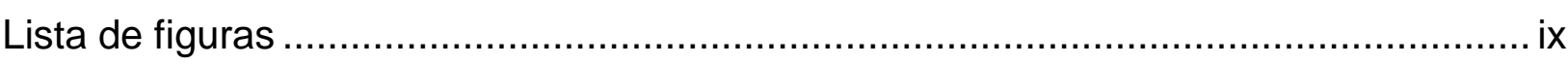

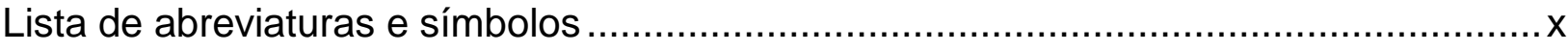

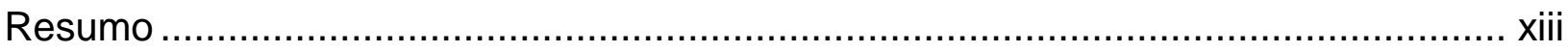

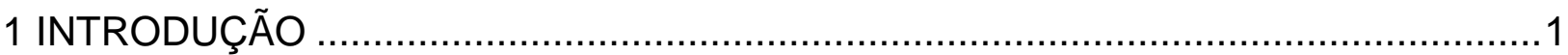

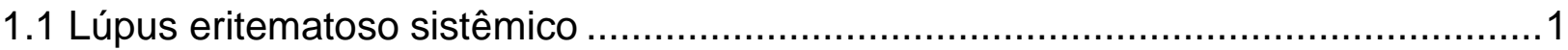

1.2 Incidência do lúpus eritematoso sistêmico ..............................................

1.3 Características genéticas e ambientais do lúpus eritematoso sistêmico ..................2

1.4 Características laboratoriais do lúpus eritematoso sistêmico ............................4

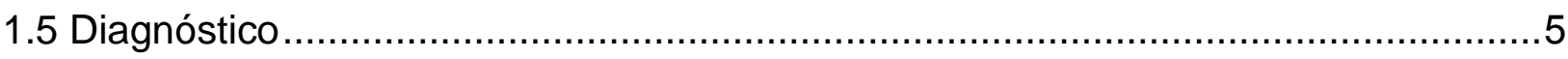

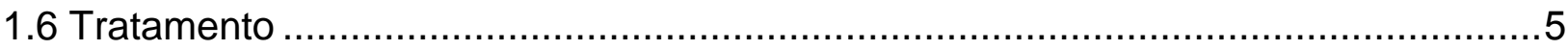

1.7 Imunologia do lúpus eritematoso sistêmico ...................................................... 7

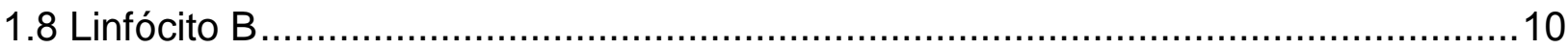

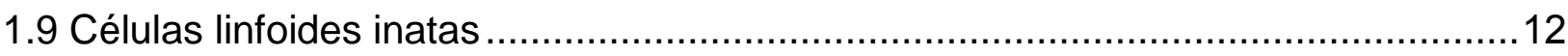

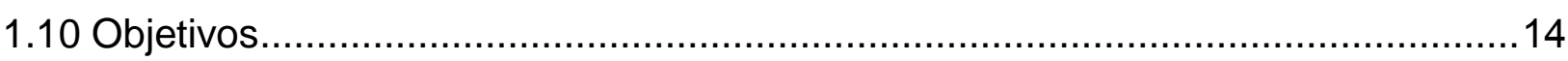

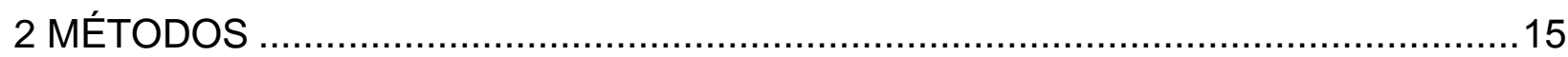

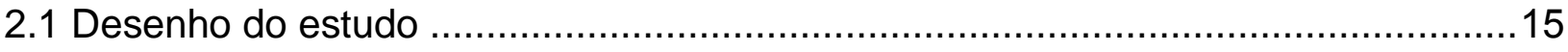

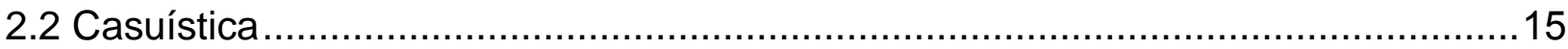

2.3 Caracterização dos participantes .............................................................. 16

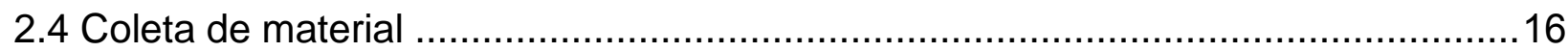

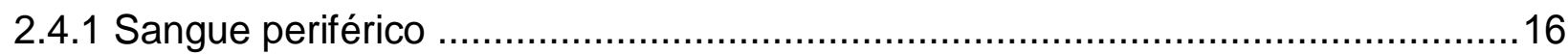

2.4.2 Células mononucleares do sangue periférico ............................................ 17

2.4.3 Pesquisa de autoanticorpos ............................................................ 18

2.4.4 Pesquisa de complemento ................................................................ 19

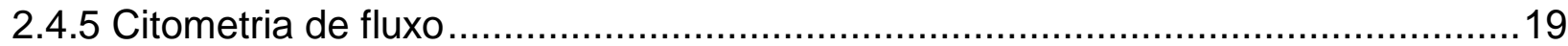

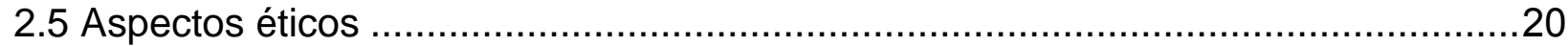

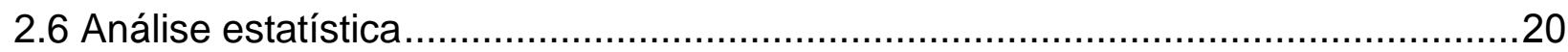

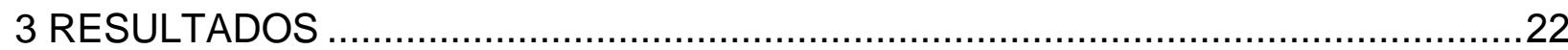

3.1 Frequência de linfócitos $B$ e suas subpopulações em pacientes com lúpus

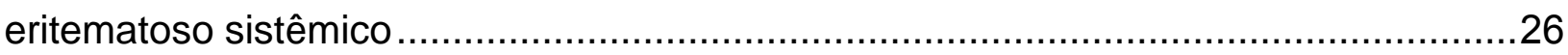


3.2 Frequência de ILC2 em pacientes com lúpus eritematoso sistêmico …………........36

3.3 Análise funcional das ILC2 em pacientes com lúpus eritematoso sistêmico 38

4 DISCUSSÃO .41

5 CONCLUSÕES .46

6 ANEXOS .47

7 REFERÊNCIAS. 49

Abstract 


\section{Lista de figuras}

Figura 1. Padrões de imunofluorescência de fatores antinucleares 4

Figura 2. Esquema de interação de células do sistema imune no lúpus eritematoso sistêmico. 8

Figura 3. Outras funções atribuídas aos linfócitos $B$ 11

Figura 4. Estratégia de análise de linfócitos $B$ total e porcentagem de linfócitos $B$......26 Figura 5. Estratégia de análise de linfócitos $B$ do centro germinativo e porcentagem de linfócitos $B$ do centro germinativo .27

Figura 6. Estratégia de análise de linfócitos B CD21 x CD27 e porcentagem das subpopulações 29

Figura 7. Estratégia de análise de linfócitos B CD21 x CD27 e porcentagem das subpopulações 31

Figura 8. Média de intensidade de fluorescência de $\mathrm{lgM}$ em pacientes com lúpus eritematoso sistêmico. 32

Figura 9. Correlação entre linfócitos $B$ de memória e linfócitos $B$ do centro germinativo em pacientes com lúpus eritematoso sistêmico .33

Figura 10. Correlação entre média de intensidade de fluorescência de $\operatorname{lgM}$ e linfócitos $B$ do centro germinativo em pacientes com lúpus eritematoso sistêmico. .33

Figura 11. Frequência de subpopulações de linfócitos $B$ em pacientes com lúpus eritematoso sistêmico e indivíduos saudáveis. 35

Figura 12. Estratégia de análise de imunofenotipagem e frequência de células linfoides inatas tipo 2 no sangue 37

Figura 13. Estratégia de análise de ensaio funcional de células linfoides inatas tipo $2 \mathrm{e}$ frequência de IL-4 e IL-13 secretadas por células linfoides inatas tipo 2 39

Figura 14. Porcentagem de células linfoides inatas tipo 2 entre pacientes com lúpus eritematoso sistêmico ativo, pacientes em baixa atividade e indivíduos saudáveis 40 


\section{Lista de tabelas}

Tabela 1. Critérios clínicos usados no sistema de classificação Systemic Lupus International Collaborating Clinics ............................................................ 5

Tabela 2. Critérios Imunológicos usados no sistema de classificação Systemic Lupus International Collaborating Clinics ............................................................... 10

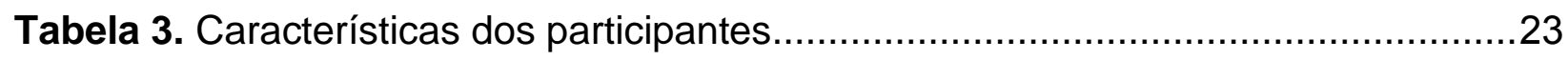

Tabela 4. Classificação da Razão de Filtração Glomerular em Doença Renal Crônica 24

Tabela 5. Classificação de Albuminúria em Doença Renal Crônica..............................24

Tabela 6. Classificação da função renal durante a fase ativa do Lúpus (V1) ..............25

Tabela 7. Classificação da função renal durante a baixa atividade/remissão do Lúpus (V2) 


\section{Lista de abreviaturas e símbolos}

ACR

AINES

Anti-dsDNA

Anti-La/SS-B

Anti-RNP

Anti-Ro/SS-A

Anti-Sm

Anti-ssDNA

BAFF

BANK-1

BCR

C3

C4

CD

$\mathrm{CH} 50$

ELISA

ES

GC

HBSS

HIV

HTLV

$\lg$

IL-

ILC

IQR

IS

LES

Ipr

$\mathrm{mAb}$

$\mathrm{mg}$
American College of Rheumatology

Anti-inflamatórios não esteroidais

Anticorpo anti-cadeia dupla de DNA

Anticorpo anti-antígeno $B$ associado à síndrome de Sjögren

Anticorpo anti-spliceossoma

Anticorpo anti-antígeno A relacionado à síndrome de Sjögren

Anticorpo anti-Smith

Anticorpo anti-cadeia simples de DNA

Fator de ativação de linfócito $\mathrm{B}$ (B-cell activating fator)

Proteína scaffold de células $B$ com repetições ankyrin 1

Receptor de célula $\mathrm{B}$ (B-cells receptor)

Complemento 3

Complemento 4

Cluster de diferenciação (Cluster of differentiation)

Complemento hemolítico 50\%

Enzimaimunoensaio (Enzyme-linked immunosorbent assay)

Esclerose sistêmica

Centro germinativo (Germinal center)

Solução salina balanceada de Hank (Hanks' balanced salt solution)

Vírus da imunodeficiência humana (Human immunodeficiency virus) $1-2$

Vírus linfotrópico da célula t humana (Human T lymphotropic virus)

Imunoglobulina

Interleucina

Célula linfoide inata (Innate lymphoid cel)

Intervalo interquartil (Interquartile range)

Indivíduo saudável

Lúpus eritematoso sistêmico

Gene de linfoproliferação

Anticorpo monoclonal (Monoclonal antibody)

Miligrama 
$\mathrm{mL}$

MRL

NK

PCR

PMA

SLEDAI

SLICC

T-bet

TCLE

VHS
Mililitro

Murphy Roths Large (camundongo)

Natural Killer

Proteína- $C$ reativa

Phorbol-12-miristato-13-acetato (Phorbol 12-myristate 13-acetate)

Systemic Lupus Erythematosus Disease Activity Index

Systemic Lupus International Collaborating Clinics

Fator de transcrição $T$-box ( $T$-box transcription factor)

Termo de Consentimento Livre e Esclarecido

Velocidade de hemossedimentação 


\section{Resumo}

Introdução: Lúpus eritematoso sistêmico é uma doença autoimune multissistêmica crônica de etiologia desconhecida. Caracterizada pela grande quantidade de autoanticorpos e acúmulo de imunocomplexos, associado à presença de linfócitos autorreativos e perda de tolerância, faz com que a patologia se mantenha ativa. Além disso, o sistema imunológico tem papel central na evolução da doença. A doença está associada principalmente aos linfócitos $B$, porém outras células do sistema imune fazem parte da patogênese do LES. Uma das células que é bastante estudada no LES é o linfócito T, com isso, analisamos as células linfoides inatas do tipo 2 das pacientes. Essas células são um grupo heterogêneo de subpopulações linfocitárias com funções que se sobrepõem aos linfócitos $T$ convencionais, e são importantes na interação da imunidade inata com a adaptativa. Objetivos: Analisar o perfil fenotípico e funcional de linfócitos $B$ e células linfoides inatas tipo 2 em pacientes com lúpus ativo e após a remissão. Métodos: Coletamos amostras de sangue de 19 mulheres portadoras de lúpus eritematoso sistêmico, no momento da atividade e baixa atividade da doença, além de sete mulheres saudáveis como controle. Realizamos o isolamento das células mononucleares de sangue periférico, através da técnica de centrifugação por gradiente de densidade. Citometria de fluxo para a caracterização fenotípica e funcional das células. Resultados: Resultados laboratoriais mostraram níveis elevados de proteína$C$ reativa, diminuição dos níveis de complemento 3 das pacientes com lúpus ativo em relação ao lúpus em baixa atividade. As células linfoides inatas tipo 2 não demonstraram nenhuma diferença de frequência e perfil funcional em ambas as fases da doença. Há subpopulações de linfócitos $B$ que estão mais expressas no lúpus em relação aos indivíduos saudáveis, além de correlação entre linfócitos $B$ derivados do centro germinativo e linfócitos $B$ de memória, e correlação da expressão de $\operatorname{lgM}$ em relação aos linfócitos $B$ do centro germinativo durante a fase ativa da doença. Conclusão: Os pacientes com lúpus ativo apresentam aumento a frequência de linfócitos $B$ derivados do centro germinativo e diminuição da expressão de IgM. Esses achados sugerem que a subpopulação de linfócitos $B$ derivados do centro germinativo podem ser utilizados como biomarcador para a doença. E a perda da expressão de lgM pode estar relacionada a presença de linfócitos B autorreativos. 


\section{INTRODUÇÃO}

\subsection{Lúpus eritematoso sistêmico}

Lúpus eritematoso sistêmico (LES) é uma doença autoimune multissistêmica crônica de etiologia desconhecida. O LES, gera uma ativação generalizada de linfócitos com produção concomitante de auto anticorpos, juntamente com a expansão de células secretoras de citocinas pró-inflamatórias das quais atacam vários órgãos. ${ }^{(1)}$

No século XIX o médico francês Laurent-Théodore Biett e seu estudante Pierre Louis Alphée Cazenave descreveram o erythema centrifugum, caracterizado por lesões de urticárias hipertróficas, sendo considerado como a premissa do LES pelos estudiosos do tema. Em 1846 o médico dermatologista austríaco Ferdinand Ritter von Hebra, descreveu as lesões de pele em forma de disco e comparou o rash malar com asas de borboleta. Mas somente no ano de 1851 que Cazenave descreve pela primeira vez a doença com a nomemclatura lúpus eritematoso, além da descrição clássica do lúpus eritematoso discóide. Cerca de vinte anos mais tarde, o dermatologista Moritz Kaposi dividiu a doença em manifestação discóide e sistêmica, sendo a segunda mais grave e podendo levar à morte, nesta mesma ocasião, Kaposi descreveu em seu artigo que os pacientes apresentavam tonsilas infartadas, dor ao deglutir, dores em articulações e ossos longos, além de febre, perda de peso e anemia. ${ }^{(2)} \mathrm{O}$ primeiro tratamento para lúpus eritematoso surgiu em 1894, onde Thomas Payne utilizou a cloroquina e elucidou a presença de distúrbios vasculares. ${ }^{(3)}$

Entre os anos de 1895 e 1904, Sir William Osler publicou 29 casos denominando-os de grupo de doenças do eritema. Osler mostrou que as doenças da pele podem ser acompanhadas por manifestações sistêmicas em alguns casos. Em um dos casos acompanhados por Osler, ele descreve o caso de uma jovem de 15 anos que apresentou rash malar, dor torácica causada por pleurite, febre e esplenomegalia. Posteriormente a paciente evoluiu com o rash nas mãos, artrite e anasarca. ${ }^{(2,3)}$

Os mesmos sintomas descritos por Osler no século XX são descritos atualmente pelo National Institute of Arthritis and Musculoskeletal and Skin Diseases do National Institutes of Health. ${ }^{(4)} \mathrm{E}$ é sabido que $O$ LES está 
relacionado a fatores genéticos e ambientais, mecanismos apoptóticos e também com a imunidade inata e adaptativa. ${ }^{(5)}$

\subsection{Incidência do lúpus eritematoso sistêmico}

Desde a descoberta do LES no século XX, a incidência da doença tem aumentado, e isso se deu por causa do avanço tecnológico para a realização de exames mais específicos e precisos. Com isso houve melhor conhecimento da doença e especialização das equipes de saúde e a criação de diretrizes, como por exemplo, os critérios de diagnóstico publicados pela American College of Rheumatology (ACR) de $1982^{(6)}$ para classificação e manejo da doença. ${ }^{(7)}$

Atualmente a estimativa de incidência e prevalência no mundo é de 0,3 a 31,5 casos para 100.000 habitantes por ano, e 3,2 a 517,5 casos para 100.000 habitantes respectivamente. Aqui no Brasil, a prevalência da doença é de 98 casos para 100.000 habitantes e a prevalência de mulheres é de 110 casos para 100.000 habitantes, enquanto a prevalência do LES em homens é de 90 casos para 100.000 habitantes. ${ }^{(7)}$

\subsection{Características genéticas e ambientais do lúpus eritematoso sistêmico}

Por se tratar de uma doença de causa desconhecida, o desenvolvimento do LES está associado a diversos eventos que podem ser relacionados a distúrbios imunológicos e fatores ambientais.

Fatores ambientais são relacionados não somente ao LES, mas a outras doenças autoimunes, como por exemplo, esclerose múltipla, doença de Graves, artrite reumatoide e colite ulcerativa. Esses fatores podem ser biológicos (agentes infecciosos), agentes físicos (radiação ionizante, exposição solar), além de agentes químicos, principalmente relacionados à sílica e/ou derivados de sílica. ${ }^{(8)} \mathrm{Um}$ estudo realizado com 258 pacientes de LES no Canadá, mostra o risco de desenvolver LES relacionado ao risco ocupacional pela exposição frequente à sílica e derivados, solventes e raios solares. As ocupações que estavam relacionadas à exposição de pó 
de sílica eram mais frequentes nos pacientes de LES. Já os pacientes que trabalhavam sob a exposição solar frequente, apresentaram maior reação cutânea. ${ }^{(9)}$

Além dos fatores ambientais, fatores genéticos também foram descritos como possíveis causadores do LES, porém os genes envolvidos nesta doença estão relacionados diretamente a doenças autoimunes e não exclusivamente ao LES. Um estudo realizado com 1000 participantes, entre pacientes de LES e indivíduos saudáveis, demonstrou que mutações relacionadas à interleucina-10 (IL-10) aumentam a produção dessa citocina, onde nos pacientes de LES, a IL-10 promove a ativação de linfócitos B. Ainda no mesmo estudo, foi possível correlacionar as alterações dos genes da IL-10 com serosite, artrite e alterações hematológicas, e desse modo uma forma mais severa do LES. ${ }^{(10)}$

Mutações relacionadas à proteína de morte celular programada 1 (PD-1), que pertence à família das imunoglobulinas (Ig) e regula a tolerância periférica dos linfócitos $T$ e $B$, também foram descritas no LES. Um estudo realizado com pacientes de LES descreveu que há diversas mutações em diferentes regiões da PD-1. Após a estratificação por etnia, apenas uma das mutações foi relacionada ao LES, onde esteve presente em $12 \%$ dos pacientes versus $5 \%$ nos indivíduos saudáveis. Essa mutação gera a perda de função da PD-1 e desse modo, há aumento de linfócitos autorreativos e hiperatividade dos mesmos. ${ }^{(11)}$

Algumas manifestações do LES puderam ser associadas à presença de SNPs na proteína ligadora de proto oncogene proteína tirosina quinase, tais como alterações hematológicas e presença de autoanticorpos anti-DNA. ${ }^{(12)} \mathrm{O}$ inibidor de resposta da célula B, proteína scaffold de células B com repetições ankyrin 1 (BANK-1) e tirosina quinase linfoide $B$ (BLK), uma das funções de BANK-1 é auxiliar a entrada de $B L K$ no linfócito $B$ através do receptor de célula $B(B C R)$, ou remover a $B L K$ da ligação com o BCR, desse modo a BANK-1 tem papel inibitório na ativação de linfócitos $B$, e a presença de polimorfismos em alguma dessas duas proteínas poderiam prejudicar a inibição da ativação dos linfócitos B. ${ }^{(13)}$

O sistema complemento é importante na resposta imune contra agentes infecciosos. Já foi descrito inúmeras vezes a importância deste sistema na patogênese do LES. Em um estudo realizado com camundongos, foi possível mostrar que a deficiência no componente C1q da via clássica do sistema complemento favorece o LES. Nesse estudo os animais que eram deficientes para o gene C1qa, apresentaram maior mortalidade e maiores titulações de autoanticorpos. ${ }^{(14)} \mathrm{O}$ mesmo 
grupo ainda mostrou que indivíduos com deficiência de C1q têm maior prevalência de LES e as manifestações da doença nessas pessoas são mais severas. O grupo ainda cita a presença de anticorpos anti-C1q nesses indivíduos. ${ }^{(15)}$

Mesmo com todos os estudos genéticos realizados nos LES, ainda não há descrição de nenhuma mutação específica para essa doença.

\subsection{Características laboratoriais do lúpus eritematoso sistêmico}

Uma das principais características do LES é a presença de anticorpos antinucleares, cerca 95\% dos pacientes com lúpus apresentam títulos altos desses autoanticorpos. O teste laboratorial padrão utilizado para o diagnóstico de anticorpos antinucleares é a imunofluorescência indireta utilizando células epiteliais humanas tipo 2 (Figura 1). Os anticorpos anti-DNA e anticorpo anti-Smith (anti-Sm) são raramente vistos em outras condições e têm alta especificidade para LES. Os títulos de anti-DNA frequentemente variam com o tempo e com a atividade de doença, por outro lado o anti-Sm é normalmente constante. ${ }^{(16)}$

A

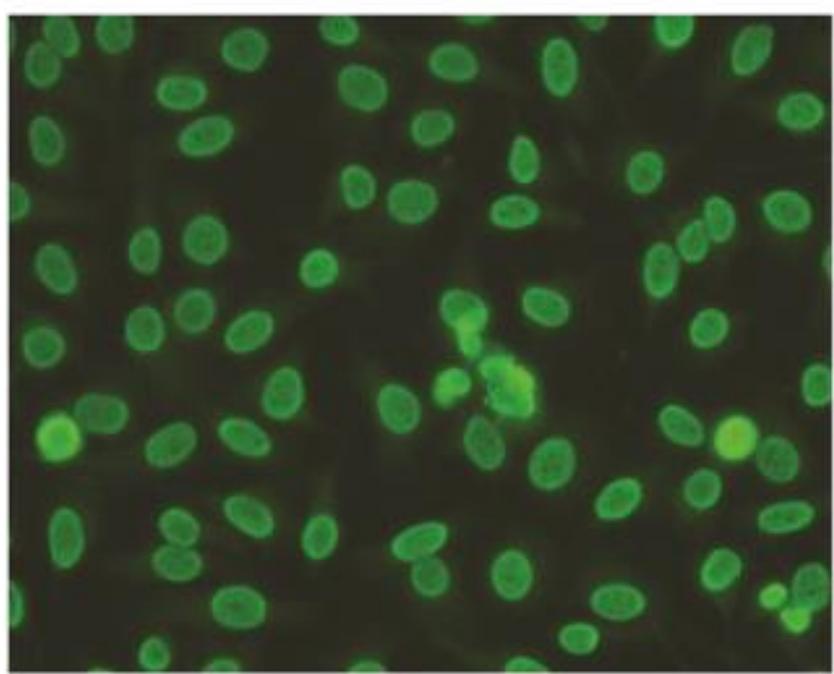

B

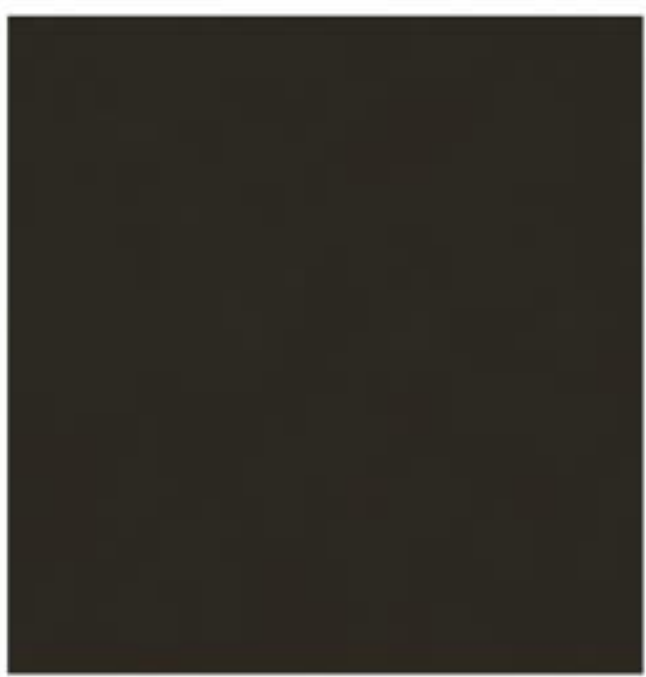

Fonte: Imagem cedida por Dra. Eliane A. Rosseto Welter, Médica Patologista Clínica Laboratório de Imunologia do Hospital Israelita Albert Einstein.

A) Titulação: nuclear homogêneo (até 1/5120) e nuclear pontilhado grosso (até 1/320). B) Controle negativo da imunofluorescência.

Figura 1. Padrões de imunofluorescência de fatores antinucleares 


\subsection{Diagnóstico}

O diagnóstico clínico de LES é realizado a partir dos sinais e sintomas, e resultados laboratoriais, fundamentado nos critérios de classificação propostos pelo ACR em 1982, ${ }^{(6)}$ e recentemente o grupo Systemic Lupus International Collaborating Clinics (SLICC) ${ }^{(17)}$ revisou e validou os critérios de classificação de LES da ACR. ${ }^{(18)}$

Em 2017 os critérios classificatórios do LES foram novamente revisados, porém o documento ainda esta em fase de desenvolvimento. ${ }^{(19)} \mathrm{Um}$ indivíduo pode ser diagnosticado com LES quando apresentar pelo menos quatro dos 11 critérios de classificação, de forma consecutiva ou seriada conforme mostrado na tabela 1:

Tabela 1. Critérios clínicos usados no sistema de classificação Systemic Lupus Internationa. Collaborating Clinics

\begin{tabular}{ll}
\hline Diagnóstico & \multicolumn{1}{c}{ Sinais e sintomas } \\
\hline 1. Lúpus cutâneo agudo & Rash malar e/ou rash maculopapular \\
2. Lúpus cutâneo crônico & Paniculite lúpica, lúpus discoide \\
3. Úlceras orais & Orofaringe \\
4. Alopecia não cicatricial & Areata (causa autoimune) \\
5. Sinovite comprometendo 2 ou mais articulações & Caracterizada por edema e/ou dor \\
6. Serosite & Derrame pleural e/ou pericárdico \\
7. Renal & Proteinúria \\
8. Neurológico & Convulsão \\
9. Anemia hemolítica & Teste de Coombs, diminuição dos eritrócitos \\
10. Leucopenia & Linfopenia abaixo de 1.000/mm ${ }^{3}$ \\
11. Trombocitopenia & Plaquetopenia abaixo de 100.000/mm ${ }^{3}$ \\
\hline Fonte: Adaptado de Petri M, Orbai AM, Alarcón GS, Gordon C, Merrill JT, Fortin PR, et al. Derivation \\
and validation of the Systemic Lupus International Collaborating Clinics classification criteria for \\
systemic lupus erythematosus. Arthritis Rheum. 2012;64(8):2677-86. ${ }^{(17)}$ \\
Tabela completa vide Anexo 1.
\end{tabular}

\subsection{Tratamento}

O tratamento do LES deve ser individualizado e aplicado de acordo com as manifestações clínicas e com o nível de gravidade da doença. Contudo, há recomendações internacionais consentidas para o tratamento de doentes com LES. ${ }^{(20,21)}$

No ano de 2008, a European League Against Rheumatism publicou recomendações para o tratamento e manejo do LES, utilizando os critérios diagnósticos 
da SLICC e critérios classificatórios da ACR. ${ }^{(22)}$ No Brasil, o controle e tratamento da doença também são guiados pelas recomendações citadas acima, onde 0 tratamento inicial é feito com antimaláricos, que visam o bloqueio de receptores tipo Toll minimizando a resposta inflamatória e diminuir a gravidade da atividade do LES. ${ }^{(21)}$

Os glicocorticoides ou anti-inflamatórios não esteroidais (AINES) também podem ser utilizados em associação aos antimaláricos. Uma vez que os pacientes não respondem ao tratamento inicial, ou não se mantém estáveis após a redução/retirada deste tratamento, pode ser indicada a utilização de Azatioprina ou Methotrexate ou Micofenolato de mofetila (imunossupressores ou antirreumáticos). Por fim, quando o paciente não responde ao tratamento citado acima, e mantém atividade elevada da doença, poderá ser indicada a administração de anticorpos monoclonais (mAb), que tem como objetivo bloquear os linfócitos $B$, diminuindo a liberação de anticorpos, inclusive os autoanticorpos. ${ }^{(21)}$

Atualmente são utilizados dois mAbs para o tratamento do LES, rituximabe e belimumabe (LymphoStat- $\mathrm{B}^{\circledR} /$ Benlysta $^{\mathrm{TM}}$ ). Rituximabe é um mAb específico para linfócitos $B$. Sua função é ligar-se ao receptor CD20 que está presente na superfície dos linfócitos $B$ maduros e de células pré-B, sendo assim ocorrerá somente à depleção desses dois grupos de linfócitos B. Esta medicação age por citotoxidade celular mediada por anticorpo, citotoxidade dependente do sistema complemento e indução da apoptose de linfócito $\mathrm{B} C D 20^{+}$. Deste modo o paciente terá menor quantidade de linfócitos $B$ circulantes e assim a doença pode ser controlada, pois haverá redução na produção de anticorpos. ${ }^{(23)}$

Belimumabe (LymphoStat- $\mathrm{B}^{\circledR} /$ Benlysta $^{\mathrm{TM}}$ ) também é um mAb, porém o seu alvo terapêutico é o fator de ativação de linfócito $B$ (BAFF), onde a principal função do BAFF é a sobrevivência e diferenciação de linfócitos $B .{ }^{(24)}$ O BAFF é uma citocina que quando é clivada, liberada uma forma solúvel e ativa, capaz de se ligar aos receptores de BAFF (BAFFR) presentes na membrana dos linfócitos $B .{ }^{(24)}$

A BAFF pertencente à superfamília do fator de necrose tumoral, e alguns pacientes com LES possuem quantidades elevadas de BAFF circulante em relação aos indivíduos saudáveis, promovendo aumento nos títulos de anticorpos antidupla fita de DNA (dsDNA), além de piorar o quadro da doença. ${ }^{(25)}$ 


\subsection{Imunologia do lúpus eritematoso sistêmico}

O LES é uma doença autoimune, e os indivíduos portadores da doença possuem altos títulos de autoanticorpos. Esses autoanticorpos são produzidos pelos plasmócitos, um subgrupo de linfócito B. Não somente os linfócitos B participam da fisiopatologia do LES, o sistema imune como todo tem participação tanto na ativação da doença como também em mantê-la ativa.

O desenho esquemático abaixo (Figura 2), publicado por Zharkova et al. em 2017, ${ }^{(26)}$ exemplifica como o sistema imunológico se comporta no LES. 


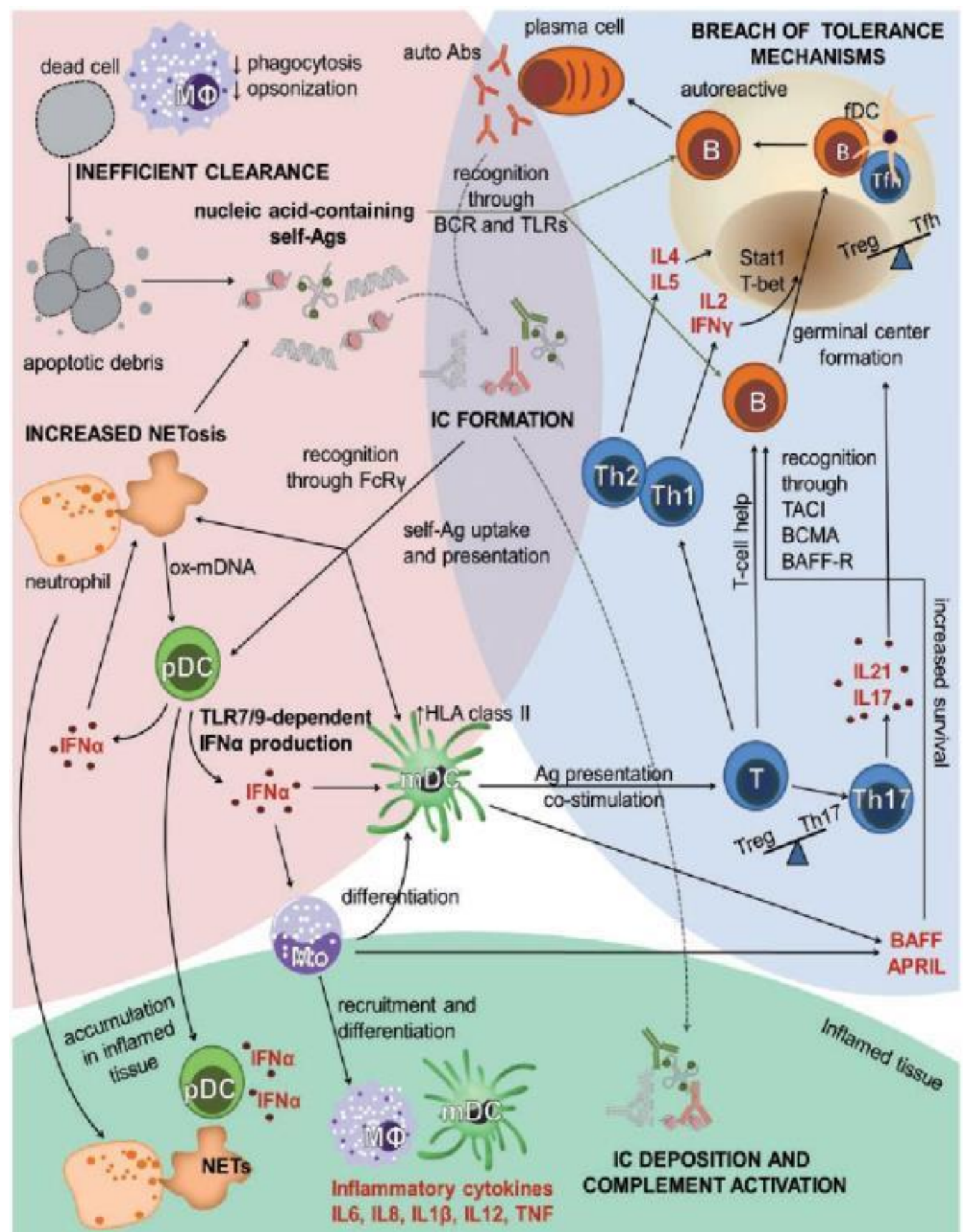

Fonte: Zharkova O, Celhar T, Cravens PD, Satterthwaite AB, Fairhurst AM, Davis LS. Pathways leading to an immunological disease: systemic lupus erythematosus. Rheumatology (Oxford). 2017;56(suppl 1):i55-66. ${ }^{(26)}$

Figura 2. Esquema de interação de células do sistema imune no lúpus eritematoso sistêmico

A figura foi dividida nos três principais mecanismos imunológicos envolvidos na doença. Apresentado em rosa observa-se algumas falhas do sistema imune inato, ressaltando principalmente a deficiência nos mecanismos de fagocitose de 
corpos apoptóticos, que contêm fragmentos de DNA e RNA, assim eles se acumulam e favorecem a formação de imunocomplexos. ${ }^{(26)}$

Em azul podemos observar a perda da tolerância imunológica, que culminará na frequente ativação dos linfócitos $B$ através da apresentação de antígenos pelas células dendríticas (DCs). Vale lembrar que os alguns antígenos apresentados pelas DCs, correspondem principalmente a fragmentos de DNA e RNA do próprio individuo, e desse modo, o linfócito $B$ que recebe essa ativação, se diferenciará em plasmócito e irá secretar autoanticorpos, conhecidos como Anticorpos Antinucleares (ANA). ${ }^{26)}$

Já a parte destacada em verde, demonstra o que ocorre nos tecidos desses pacientes. Os imunocomplexos que se formam tendem a se acumular nos tecidos, e em resposta ocorre migração de monócitos e de DCs, mantendo o tecido inflamado através da secreção de citocinas pró-inflamatórias. Além disso, o acúmulo de imunocomplexos nos tecidos ativa o sistema complemento, que tem como função destruir imunocomplexos, e este mecanismo que caracteriza a queda das frações complemento 3 (C3) e complemento 4 (C4) do sistema complemento nos indivíduos com LES. ${ }^{(26)}$

Além das funções das células descritas acima, incluem também a secreção de citocinas pró-inflamatórias (IL-4, IL-5, IL-6, IFNa) e fatores de ativação e manutenção celular, como por exemplo, BAFF. Desse modo a resposta imune se mantém ativada, pois como pudemos observar, no LES além das falhas descritas, o sistema imune está desbalanceado, onde os fatores pró-inflamatórios se sobrepõem aos fatores anti-inflamatórios. ${ }^{(26)}$

Desse modo, analisando a resposta imunológica na patologia do LES, a SLICC descreve alguns critérios imunológicos dentro dos critérios classificatórios do LES: 
Tabela 2. Critérios Imunológicos usados no sistema de classificação Systemic Lupus International Collaborating Clinics

\begin{tabular}{|c|c|}
\hline Exames realizados & Interpretação \\
\hline 1. FAN & Positivo \\
\hline 2. Anti-dsDNA & Positivo \\
\hline 3. Anti-Sm & Positivo \\
\hline 4. Anticorpo antifosfolípide & $\begin{array}{l}\text { Anticoagulante lúpico positivo, médios ou altos títulos de } \\
\text { anticorpo anticardiolipina (IgA, IgG, IgM) Anti-2-glicoproteína I } \\
\text { (IgA, IgG, or } \lg M) \text { positivo }\end{array}$ \\
\hline 5. Queda de complemento & $\mathrm{C} 3 ; \mathrm{C} 4 ; \mathrm{CH} 50$ \\
\hline 6. Coombs' direto & Positivo na ausência de anemia hemolítica \\
\hline
\end{tabular}

FAN: fator antinuclear; Anti-dsDNA: anticorpos anti dupla fita de DNA; Anti-Sm: anticorpos antiSmith. Tabela completa vide Anexo 1.

Fonte: Adaptado de Petri M, Orbai AM, Alarcón GS, Gordon C, Merrill JT, Fortin PR, et al. Derivation and validation of the Systemic Lupus International Collaborating Clinics classification criteria for systemic lupus erythematosus. Arthritis Rheum. 2012;64(8):2677-86. ${ }^{(17)}$

\subsection{Linfócito B}

$\mathrm{Na}$ medula óssea ocorre a diferenciação de células-tronco hematopoiéticas nos diversos tipos celulares presentes no sangue, incluindo a linfopoiese, processo de formação dos linfócitos $T$ e linfócitos B. Após essa diferenciação, os linfócitos $T$ devem passar pelo Timo para que finalizem a sua maturação, e os linfócitos $B$ devem passar pelos centros germinativos (GC) localizados em órgãos linfoides secundários, como por exemplo, os linfonodos. Além disso, os linfócitos B são divididos em subpopulações de acordo com o fenótipo e função. ${ }^{(27)}$

Os linfócitos $B$ naives fazem parte de uma subpopulação de linfócitos $B$, caracterizados pelo fenótipo $\operatorname{lgD}^{+}$e CD27. ${ }^{(28)}$ Estão predominantemente nos GCs, onde ocorrem ativação e proliferação celular, hipermutação somática, troca de isotipos de Ig e seleção positiva ou negativa para antígenos. ${ }^{(29)}$

Após passarem pelos processos citados acima, os linfócitos $B$ tornam-se linfócitos maduros, onde são classificados pela presença de $\operatorname{lgM}$ e $\lg D$ em sua membrana, e esses linfócitos podem ser ativados no GC, e dessa forma se diferenciar em uma célula $B$ de memória. ${ }^{\left({ }^{30}\right)}$ As células $B$ de memória são células que foram ativadas e responderam a um antígeno, após sua função executada essas células retornam ao seu estado quiescente ("resting memory") até que sejam requisitadas novamente. ${ }^{(31)}$

Outra subpopulação de linfócitos B é composta por plasmócitos, células especializadas em secretar anticorpos, conhecidos também como Ig. A principal 
função dos plasmócitos é manter a resposta humoral, em alguns casos, a memória humoral pode se manter por toda a vida do indivíduo. ${ }^{(32)}$ Os plasmócitos são divididos em dois grupos, Plasmócito de vida curta ("short-lived plasma cell"), onde tendem a durar aproximadamente uma semana no meio extra folicular, o segundo grupo é chamado de Plasmócito de vida longa ("Iong-lived plasma cell'), esse grupo é capaz de durar cerca de 18 semanas ou mais. ${ }^{(33)}$ Sabe-se também que os níveis circulantes das subclasses de anticorpos IgG e IgA podem se manter estável durante anos, mas mesmo assim, há uma fração de plasmócitos que ficam alocados na medula óssea para garantir que os títulos de anticorpos específicos se mantenham circulantes no indivíduo. ${ }^{(33)}$

Outras funções atribuídas aos linfócitos B (Figura 3) é a de apresentação de antígenos, porém não tão eficaz como as células dendríticas, além de participarem de reparo tecidual e organogenese de tecidos linfoides. ${ }^{(30)}$ Porém a principal função do linfócito $B$ é a síntese de anticorpos, tanto como primeira resposta imunológica, como na resposta imune adaptativa através de secreção de anticorpos específicos, além disso, são os linfócitos B responsáveis pela secreção de autoanticorpos no contexto de doenças autoimunes, como por exemplo, o LES. ${ }^{(29,34,35)}$

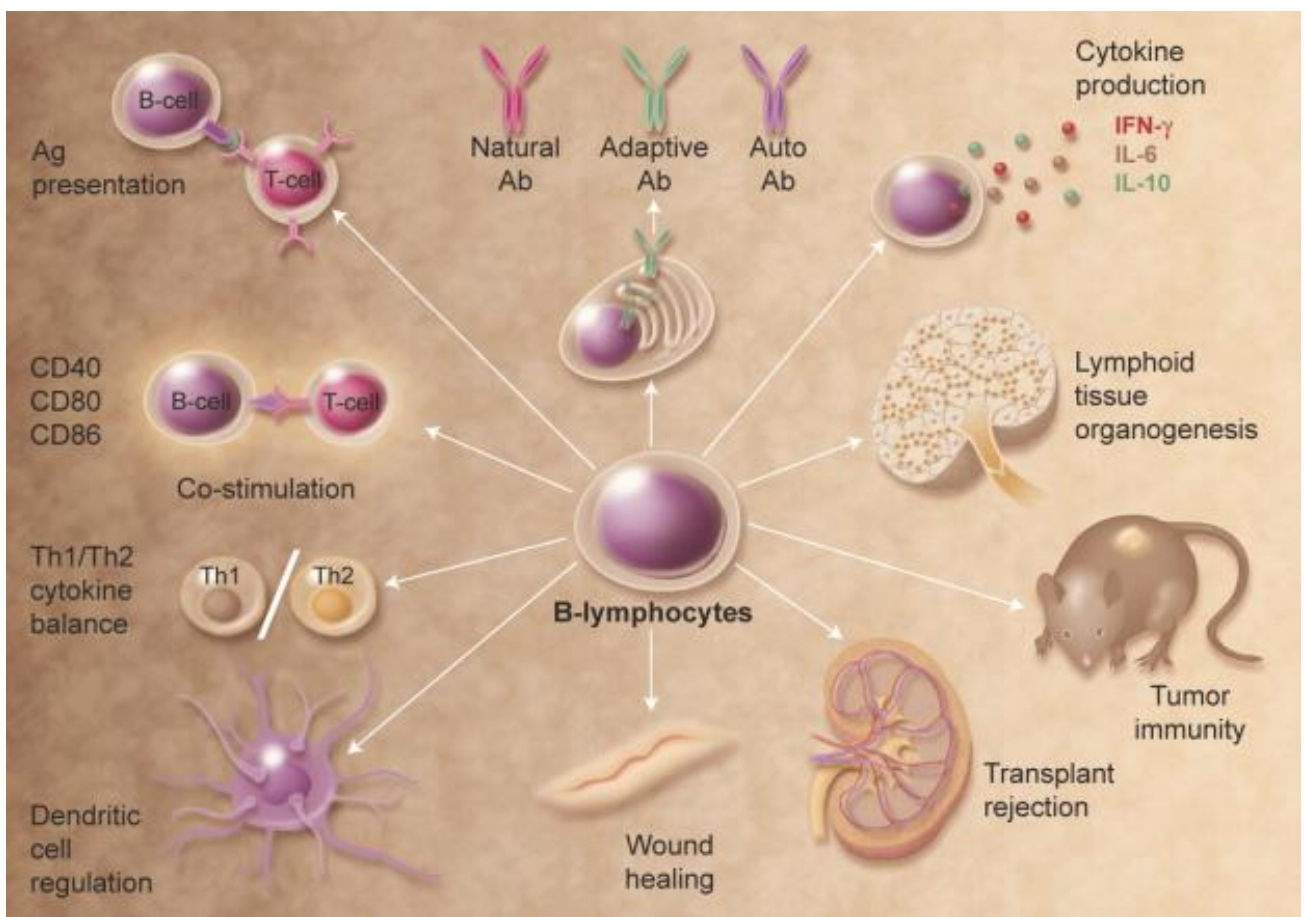

Fonte: LeBien TW, Tedder TF. B lymphocytes: how they develop and function. Blood. 2008;112(5):1570-80. ${ }^{(30)}$

Figura 3. Outras funções atribuídas aos linfócitos $B$ 
Estudo feito em 1994 por Shlomchik et al. fala sobre a atuação dos linfócitos B em doenças autoimunes, onde eles realizaram ablação total dos linfócitos B em uma linhagem de camundongos com manifestações autoimunes (MRL/lpr/lpr), e puderam observar que os animais obtiveram regressão total das manifestações autoimunes. ${ }^{(36)}$

O LES é caracterizado pela hiper-reatividade dos linfócitos $B$ e pela alta produção de anticorpos pelos plasmócitos. Além disso, a produção de anticorpos pode ser dada de forma espontânea nessa patologia, não necessitando de um estímulo especifico. Essas células produzem grandes quantidades de lgG em comparação a indivíduos saudáveis, ${ }^{(37)}$ e em pacientes com LES ativo possuem maior quantidade de células que secretam anticorpos anti-DNA, quando são comparados com indivíduos saudáveis ou pacientes com LES em remissão. ${ }^{(38)}$

\subsection{Células linfoides inatas}

Células linfoides inatas (ILC - Innate lymphoid cells), são células que apresentam morfologia linfoide, e que não possuem receptores para antígenos específicos, receptores de linfócito T ou BCR. ${ }^{(39)}$ As ILCs são provenientes de célulastronco hematopoiéticas positivas para inibidor de ligação de DNA 2, e necessitam de IL-7, IL-15, IL-23, IL-25 e IL-33 para seu desenvolvimento, onde o estímulo de cada citocina fará com que as células expressem fatores de transcrição e secretem citocinas diferentes para cada um dos três subgrupos de ILC. ${ }^{(40)}$ A função dessas células se assemelha aos linfócitos $\mathrm{T}$ helpers, pois são células especializadas em secretar citocinas de características Th1, Th2 e Th17, e estão localizadas em sua maior parte na superfície de mucosas e respondem aos estímulos liberados pelas células epiteliais. ${ }^{(41)}$

Fazem parte das ILCs tipo I, as células Natural Killers (NKs), onde sua principal característica é a secreção de IFN-y, TNF--.e fatores citotóxicos, dependentes dos fatores de transcrição Eomesodermina e Fator de transcrição T-box (T-bet - T-box transcription factor), as NK são células são importantes na resposta imune contra vírus, células cancerígenas e na inflamação crônica. Ainda nesse subgrupo temos as próprias ILCs do tipo I (ILC1), que diferente das NKs as ILC1 foram classificadas como células não citotóxicas, e a principal citocina secretadas por elas é 
IFN- $y$, onde predomina a expressão do T-bet, a principal função dessas células é de promover resposta imune contra bactérias e protozoários intracelulares, e também estão presentes na inflamação crônica. ${ }^{(40,42)}$

As ILCS tipo II (ILC2) são células que apresentam perfil de citocinas Th2, secretando principalmente IL-4, IL-5 IL-9 e IL-13, onde o fator de transcrição predominante é o fator de transcrição de ação "trans" específico de células T GATA3. ${ }^{(41)}$ Por possuírem perfil de resposta imune Th2, as ILC2 estão relacionadas principalmente a infecções parasitárias causadas por helmintos, através da secreção de IL-13, promovendo dessa forma aumento da secreção de muco pelas células caliciformes intestinais e aumento do peristaltismo intestinal, desse modo facilitando a expulsão do parasita. ${ }^{(41)}$

As ILC2 também expressam em sua superfície receptores de IL-25 (IL17BR) e IL-33 (ST2), citocinas essas que são liberadas por células epiteliais, como por exemplo, a mucosa das vias aéreas. Em situações como hipersensibilidade das vias aéreas após exposição à alergenos, as ILC2 recebem o estímulo de IL-33 e IL-25 proveniente da mucosa respiratória, desencadeando a liberação de IL-4, IL-13, IL-5 e IL-9 pelas ILC2, que recrutarão ao sítio inflamatório eosinófilos, mastócitos e macrófagos. Desse modo haverá aumento da secreção de muco pelas células ciliares presentes na mucosa respiratória, facilitando a eliminação dos alergenos. Além da secreção de citocinas Th2, as ILC2 também irão secretar Anfiregulina, que fará com que o tecido do sítio inflamatório seja reparado, e o mesmo mecanismo de reparo é observado após infecções por vírus da influenza. ${ }^{(39,41)}$

Wohlfahrt et al. realizaram um trabalho com 69 pacientes portadores de esclerose sistêmica (ES), também de característica autoimune, e o principal achado do grupo foi o aumento da frequência de ILC2 tanto em sangue quanto em tecido cutâneo, e esse número aumenta quando os pacientes possuem fibrose difusa e/ou fibrose pulmonar. Observaram também correlação positiva no número de ILC2 na pele dos indivíduos que possuíam valores maiores que dez na escala de extensão de fibrose (Escala Rodnan Modificada). Outro fato curioso descrito pelos autores foi de que as ILC2 estavam ativadas na pele, utilizando como marcadores de ativação TSLPR $^{+}$, IL17RB ${ }^{+}$e ST2 ${ }^{+}$, o mesmo fenótipo não foi observado nas ILC2 circulantes desses pacientes. ${ }^{(43)}$

Já as ILCs tipo III (ILC3) possuem perfil de citocinas Th17, secretando IL-17 e/ou IL-22, dessa forma são dependentes do fator de transcrição 
receptor órfão relacionado ao receptor de ácido retinoico gama. No início da descoberta das ILCs, as ILC3 eram tidas como células indutoras de tecido linfoide (LTi), porém hoje já se sabe que a principal característica que as diferem é a expressão do receptor de desencadeamento de citotoxidade natural 1 nas ILC3, e da expressão do receptor de quimiocina 6 (CCR6) nas LTi. Além disso, as ILC3 podem apresentar o fenótipo $\left(\mathrm{CCR6}^{-}, \mathrm{NCR}^{+}\right)$, que predominantemente secreta IL-22. Além disso, as ILC3 que possuem NKp46- secretam IL-17, IFNy e IL-22. ${ }^{(41,42)}$ Essas células se fazem importantes para combaterem infecções por bactérias extracelulares, além de participarem do desenvolvimento de tecidos linfoides, homeostase intestinal e também participam da resposta imune na inflamação crônica. ${ }^{(41)}$

Como não há trabalhos na literatura que relacionem as ILC2 com o LES, desse modo, nós hipotetizamos que a secreção de IL-4 e IL-13 pelas ILC2 poderiam estar relacionadas à ativação dos linfócitos $B$, e desse modo fazer com que os linfócitos se diferenciassem em plasmócitos e assim, produzirem anticorpos/autoanticorpos, mantendo o LES ativo.

\subsection{Objetivos}

1. Analisar a frequência e funcionalidade de linfócitos $B$ e seus fenótipos de ativação e memória no sangue de pacientes com lúpus ativo e após remissão.

2. Analisar a frequência e funcionalidade das células ILC2 no sangue de pacientes com lúpus ativo e após remissão. 


\section{MÉTODOS}

\subsection{Desenho do estudo}

Este trabalho foi desenvolvido como um estudo prospectivo, com a participação voluntária dos sujeitos da pesquisa.

\subsection{Casuística}

Foram incluídos neste estudo, apenas amostras de indivíduos com lúpus. Todos os participantes assinaram o Termo de Consentimento Livre e Esclarecido (TCLE) antes de serem incluídos no estudo (CAAE 37106714.9.1001.0071).

A inclusão de voluntários (grupos) seguiu os seguintes critérios de inclusão e exclusão:

Grupo 1: Lúpus Ativo

Critérios de inclusão

Idade igual ou superior a 18 anos completos;

Indivíduos com ausência de infecção caracterizada no hemograma de paciente com lúpus por citopenia, com linfopenia, que indiretamente não indica algum tipo de infecção viral e/ou bacteriana;

Indivíduos com sorologia negativa para: vírus da imunodeficiência humana (HIV - human immunodeficiency virus)1-2; vírus linfotrópico da célula $\mathrm{t}$ humana (HTLV - Human T lymphotropic virus) 1/2; sífilis; vírus da hepatite C (HCV hepatitis $C$ virus) e vírus da hepatite $\mathrm{B}$ (HBV - hepatitis $B$ virus);

Em uso de corticoides até $20 \mathrm{mg} /$ dia.

Critérios de exclusão

Incapacidade de entender o TCLE;

Uso de drogas que comprometam o julgamento para a participação no estudo;

Uso de corticoides acima de $20 \mathrm{mg} /$ dia ou imunossupressores.

Grupo 2: Lúpus em Remissão

Critérios de inclusão

Idade igual ou superior a 18 anos completos; 
Indivíduos com ausência de infecção caracterizada no hemograma de paciente com lúpus por citopenia, com linfopenia, que indiretamente não indica algum tipo de infecção viral e/ou bacteriana;

Indivíduos com sorologia negativa para: HIV1-2; HTLV1/2; sífilis; HCV e HBV;

Pacientes em uso de corticoides e imunossupressores.

Critérios de exclusão

Incapacidade de entender o TCLE;

Uso de drogas que comprometam o julgamento para a participação no estudo.

\subsection{Caracterização dos participantes}

As voluntárias da nossa pesquisa são pacientes do ambulatório de Reumatologia da Irmandade da Santa Casa de Misericórdia de São Paulo. Foram recrutadas 19 mulheres portadoras de LES, onde a mediana de idade das participantes da pesquisa é equivalente em relação às duas visitas (Tabela 3). A caracterização completa das participantes da pesquisa está descrita nas tabelas Suplementar 1 e 2. Incluímos também neste trabalho sete mulheres saudáveis para utilizarmos como controle. Todos os valores correspondem à Mediana (M) e IQR.

O rendimento celular após o descongelamento das amostras das participantes de LES foi muito baixo, por conta disso, o número amostral da fenotipagem de linfócitos $B$ foi $n=11$ na primeira e segunda visita. Em relação ao número amostral da fenotipagem de ILC2 foi $n=15$ na primeira e segunda visita.

\subsection{Coleta de material}

\subsubsection{Sangue periférico}

Foram coletados 90 mililitros $(\mathrm{mL})$ de sangue periférico por punção venosa em membro superior de indivíduos pertencentes a este estudo, após cuidadosa assepsia local. Este volume de $90 \mathrm{~mL}$ não prejudica a saúde do indivíduo, 
determinamos este volume máximo, pois devido à quantidade baixa de ILC na periferia. ${ }^{(44)}$

A coleta de sangue foi realizada através da técnica de coleta a vácuo, que compreende na punção da veia do paciente permitindo que o sangue flua diretamente para o tubo de coleta a vácuo. Esta técnica é ideal, pois possibilita a coleta de vários tubos e se caracteriza por ser um sistema fechado e sem a necessidade de manuseio com a amostra.

O material foi coletado no ambulatório da Santa Casa de Misericórdia de São Paulo, e foi processado até 24 horas pós a coleta.

Os procedimentos laboratoriais foram realizados em cabine de segurança biológica devidamente esterilizada. E foi realizada a separação das células mononucleares e criopreservadas em nitrogênio líquido para realizar os ensaios imunológicos utilizando a técnica de citometria de fluxo.

Destas amostras também foi separado e congelado a $-80^{\circ} \mathrm{C}$, soro coletado em um tubo adicional sem anticoagulante.

Foi realizado com 100 microlitros de sangue total para quantificação de subpopulações linfocitárias (com o painel CD3/CD4/CD8).

Segue abaixo o detalhamento das técnicas dos procedimentos citados acima.

\subsubsection{Células mononucleares do sangue periférico}

Em ambiente estéril, o sangue coletado em tubo contendo ácido cítrico citrato de sódio e dextrose (ACD) (BD Vacutainer ${ }^{\circledR}$ - Ref 364406) foi diluído na proporção de 1:1 em solução salina balanceada de Hank (HBSS - Hanks' Balanced Salt solution) (GIBCO® - ThermoFisher Cat No. 14025092) e posteriormente transferido cuidadosamente para tubos contendo Ficoll (Ficoll@ Paque Plus - SigmaAldrich Cat No. GE17-1440-02 SIGMA). Em seguida as amostras devem ser centrifugadas a 2300 rotações por minuto $(\mathrm{rpm})$, com temperatura entre $18^{\circ} \mathrm{C}$ e $20^{\circ} \mathrm{C}$, durante 40 minutos, aceleração de 4 e desaceleração 0.

Após a finalização da centrifugação, é coletada a "nuvem" que contém as células CMSP, cuidadosamente com uma pipeta Pasteur estéril, e colocada em um novo tubo, ao final completa-se o volume do tubo com HBSS e será realizada 
uma centrifugação a uma velocidade de $1700 \mathrm{rpm}$, com temperatura entre $18^{\circ} \mathrm{C}$ e $20^{\circ} \mathrm{C}$, durante 10 minutos, aceleração de 9 e desaceleração de 9 . Esta etapa deve ser feita duas vezes, e após o termino da segunda centrifugação, será adicionado ao pellet formado, solução de lise de hemácias Ammonium-Chloride-Potassium ACK Lysing Buffer - GIBCO® - ThermoFisher Cat No. A1049201 e aguardar dois minutos. Após esse período, deve colocar meio R-10 para inativar a ação do ACK e será realizada nova centrifugação com os mesmos parâmetros ao passo anterior. Ao final será realizada a contagem celular e verificação de viabilidade da amostra.

A viabilidade celular foi definida utilizando o corante Tripan Blue (Azul de tripan) e em seguida, foi feita diluição e correção da concentração celular através da contagem celular no Countess $^{\mathrm{TM}}$ /I Automated Cell Counter. Após os cálculos, promovemos nova centrifugação a uma velocidade de 1700rpm, com temperatura entre $18^{\circ} \mathrm{C}$ e $20^{\circ} \mathrm{C}$, durante 10 minutos, aceleração de 9 e desaceleração de 9. Após este passo, as amostras devem ser ressuspendidas em meio de congelamento. As células foram transferidas para criotubos nos quais permaneceram no freezer a $-80^{\circ} \mathrm{C}$ durante 24 horas e em seguida transferidos para o tanque de nitrogênio líquido.

Todas as amostras permaneceram estocadas no laboratório de Patologia Clínica do Hospital Israelita Albert Einstein até o momento da realização dos experimentos.

\subsubsection{Pesquisa de autoanticorpos}

A pesquisa de autoanticorpos foi realizada no laboratório clínico do Hospital Israelita Albert Einstein. Foi realizada através do equipamento Quanta-Lyser 240 (Inova Diagnostics, Inc.), que permite análise de imunofluorescência utilizando tecnologia digital e propriedades algoritmias para capturar a intensidade da imagem e criar detalhes para posterior revisão. Os principais autoanticorpos para a confirmação do LES foram realizados, tais como: anticorpo anti-cadeia dupla de DNA (anti-dsDNA); anticorpo anti-cadeia simples de DNA (anti-ssDNA); anti-Sm; anticorpo antispliceossoma (anti-RNP); anticorpo anti-antígeno A relacionado à síndrome de Sjögren (anti-Ro/SS-A) e anticorpo anti-antígeno B associado à síndrome de Sjögren (antiLa/SS-B). 


\subsubsection{Pesquisa de complemento}

Foi realizada a pesquisa de complemento total pela metodologia de enzimaimunoensaio (ELISA - Enzyme-linked immunosorbent assay) utilizando o kit da Diasorin. Para as frações C3 e C4 foi utilizada através da metodologia de nefelometria, utilizando o equipamento BNII ${ }^{\mathrm{TM}}$ (Siemens $^{\circledR}, \mathrm{AG}$ ). Todos os exames laboratoriais foram realizados pelo laboratório clinico do Hospital Israelita Albert Einstein, de acordo com os protocolos institucionais de qualidade.

\subsubsection{Citometria de fluxo}

A imunofenotipagem de superfície e a técnica intracelular foram realizadas no FACS Fortessa de 14 cores.

Para caracterização de linfócitos B e subpopulações foram utilizados os seguintes anticorpos: anti-CD3 (clone: UCHT1), anti-CD14 (clone:

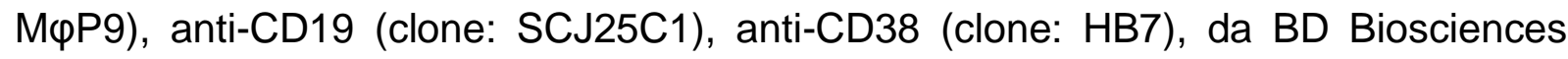
(San Jose, CA, USA); anti-lgD (clone: IA6-2), anti-CD21 (clone: Bu32), anti-CD27 (clone: 323) e anti-IgM (clone: MHM88) da Biolegend (San Diego, CA, USA). Para a caracterização das ILC2 foram utilizados os anticorpos anti-CD161 (clone: DX12), anti-CD45 (clone: 2D1) anti-LIN cocktail, anti-CD25 (clone: M-A251) e anti-CD294 (clone: BM16) da BD Biosciences (San Jose, CA, USA) e Amine Aqua dye (Invitrogen, Carlsbad, CA, USA) foi utilizado para excluir as células mortas de todos os experimentos. As amostras foram lavadas, e posteriormente fixadas com formaldeído antes da aquisição no citômetro de fluxo.

Para o protocolo de marcação de citocinas intracelulares, as amostras de células mononucleares do sangue periférico foram descongeladas e incubadas na presença de 100ng/mL Phorbol-12-miristato-13-acetato (PMA - phorbol 12-myristate 13-acetate) (Sigma) e 500ng/mL ionomycin (Sigma). Após 1 hora na incubadora cellular, a temperature de $37^{\circ} \mathrm{C}$ e $5 \% \mathrm{CO}_{2}$, adicionamos Monensina (Golgi Stop, BD Biosciences) e Brefeldina A (Golgi Plug, BD Biosciences). ${ }^{(45)}$ Após incubação de aproximadamente 16 horas, as células foram lavadas, e incubadas com os anticorpos de superfície. Após esse período, as células foram lavadas e permeabilizadas/fixadas com o reagente fixation/permeabilization da Life Technologies 
de acordo com as instruções do fabricante. As células foram incubadas com anti-IL-4 (clone: MP4-25D2) e anti-IL-13 (clone: JES10-A23) da BD Biosciences ${ }^{\mathrm{TM}}$ (San Jose, CA, USA).

Para as estratégias de análises de superfície, utilizamos a técnica de Fluorescence minus one $(\mathrm{FMO}) .{ }^{(46)} \mathrm{E}$ amostras não estimuladas foram utilizadas para as estratégias dos experimentos intracelulares.

Foram realizados testes de controle de qualidade no equipamento, para assegurar a qualidade e objetividade dos experimentos. As analises foram realizadas pelo software FlowJo, específico para análises de citometria de fluxo. Todas as técnicas de citometria foram realizadas com controles positivos e negativos, como também marcação de viabilidade celular utilizando LIVE/DEAD ${ }^{\mathrm{TM}}$ Fixable Aqua Dead Cell Stain Kit (InvitrogenTM - Cat No. L34957).

\subsection{Aspectos éticos}

A participação de voluntários neste projeto ficou condicionada à leitura, compreensão e assinatura de TCLE, e todos foram informados que podem abandonar o estudo a qualquer momento, sem que os seus direitos à assistência médica e demais cuidados de saúde na instituição sejam prejudicados.

Os voluntários não foram submetidos a qualquer forma de intervenção experimental envolvendo drogas ou vacinas. Os riscos a que os voluntários foram submetidos eram mínimos, relacionados à punção venosa. Houve os riscos inerentes à punção venosa, que raramente podem causar dor, hiperemia local ou um pequeno hematoma.

O início deste estudo deu-se após a aprovação do Comitê de Ética em Pesquisa (CAAE 37106714.9.1001.0071), e a instituição coordenadora do estudo é o Hospital Israelita Albert Einstein.

\subsection{Análise estatística}

Para a realização da análise estatística dos resultados apresentados no presente estudo, foi utilizado o programa GraphPad Prism versão 6.0c para Mac 
OS, onde atribuímos o teste T pareado ou teste de Wilcoxon, One-way ANOVA ou Kruskal-Wallis e correlação de Pearson ou Spearman. Utilizamos o teste de ShapiroWilk para determinar a distribuição das amostras através do programa versão 3.19 para Mac OS, e atribuímos o valor de significância de 5\% $(p \leq 0,05)$. Para a representação gráfica das análises, utilizamos mediana $(\mathrm{M})$ e intervalo interquartil (IQR - Interquartile range). 


\section{RESULTADOS}

O Systemic Lupus Erythematosus Disease Activity Index (SLEDAI) é uma ferramenta utilizada para identificar o nível de atividade do LES. O SLEDAI classifica a atividade da doença através de valores numéricos da seguinte forma: LES inativo: 0, Atividade leve: 1 a 5, Atividade moderada: 6 a 10, Atividade alta: 11 a 19 e Atividade muito alta: $\geq 20 .{ }^{(47)}$ No presente estudo, foi utilizada a versão em 2002 chamada de Systemic Lupus Erythematosus Disease Activity Index 2000 SLEDAI$2 \mathrm{~K}) .{ }^{(47)} \mathrm{O}$ valor do SLEDAI nos mostrou que durante a $\mathrm{V} 1$ os pacientes apresentavam atividade moderada a alta [V1: $\mathrm{M}=9(\mathrm{IQR}=6: 12)]$, já na V2 os pacientes estavam com LES inativo ou em atividade leve [V2: $M=2(I Q R=0: 4)]$ (Tabela 3).

A análise das subpopulações linfócitos CD4 e CD8, observamos que há diminuição da frequência dos linfócitos CD8 durante a Visita 1 (V1 - LES ativo) em comparação à Visita 2 (V2 - LES em baixa atividade) [V1: M = 281 (IQR = 201:472) V2: $M=459$ (IQR = 274:707)] (Tabela 3). Já está estabelecido na literatura que o consumo de frações do sistema complemento C3 e C4 são indicadores de atividade do LES. Na população do nosso estudo não observamos diferenças significantes nos valores de complemento total (CH50) [V1: $M=73(I Q R=28: 105)$ V2: $M=103(I Q R=60: 129)]$ e da fração C4 do sistema complemento [V1: $\mathrm{M}=10$ (IQR = 8:18) V2: $\mathrm{M}=14$ (IQR = 7:22)] entre a V1 e V2 (Tabela 3). Porém os valores da fração C3 do sistema complemento durante a V1 foi menor quando comparado à V2 [V1: $\mathrm{M}=74$ (IQR = 55:90) V2: $M=85$ (IQR = 63:107)], dado que demonstra que após a diminuição da atividade do LES, os indivíduos recuperam os valores normais de C3 (Tabela 3).

Em relação aos exames bioquímicos e hematológicos de Creatinina, Ureia, velocidade de hemossedimentação (VHS) e hemoglobina não se observou diferenças significativas nos pacientes com LES ativo e após a diminuição de atividade da doença, porém os valores de proteína-C reativa (PCR) estavam aumentados na $\mathrm{V} 1$ em relação à V2 [V1: $M=5(I Q R=1: 14)$ V2: $M=2(I Q R=1: 6)]$, o PCR é um marcador inespecífico de processo inflamatório, e os pacientes que estão com a doença ativa estão passando por um processo inflamatório sistêmico, assim justificando a queda do PCR no momento de baixa atividade da doença (Tabela 3). 
Tabela 3. Características dos participantes

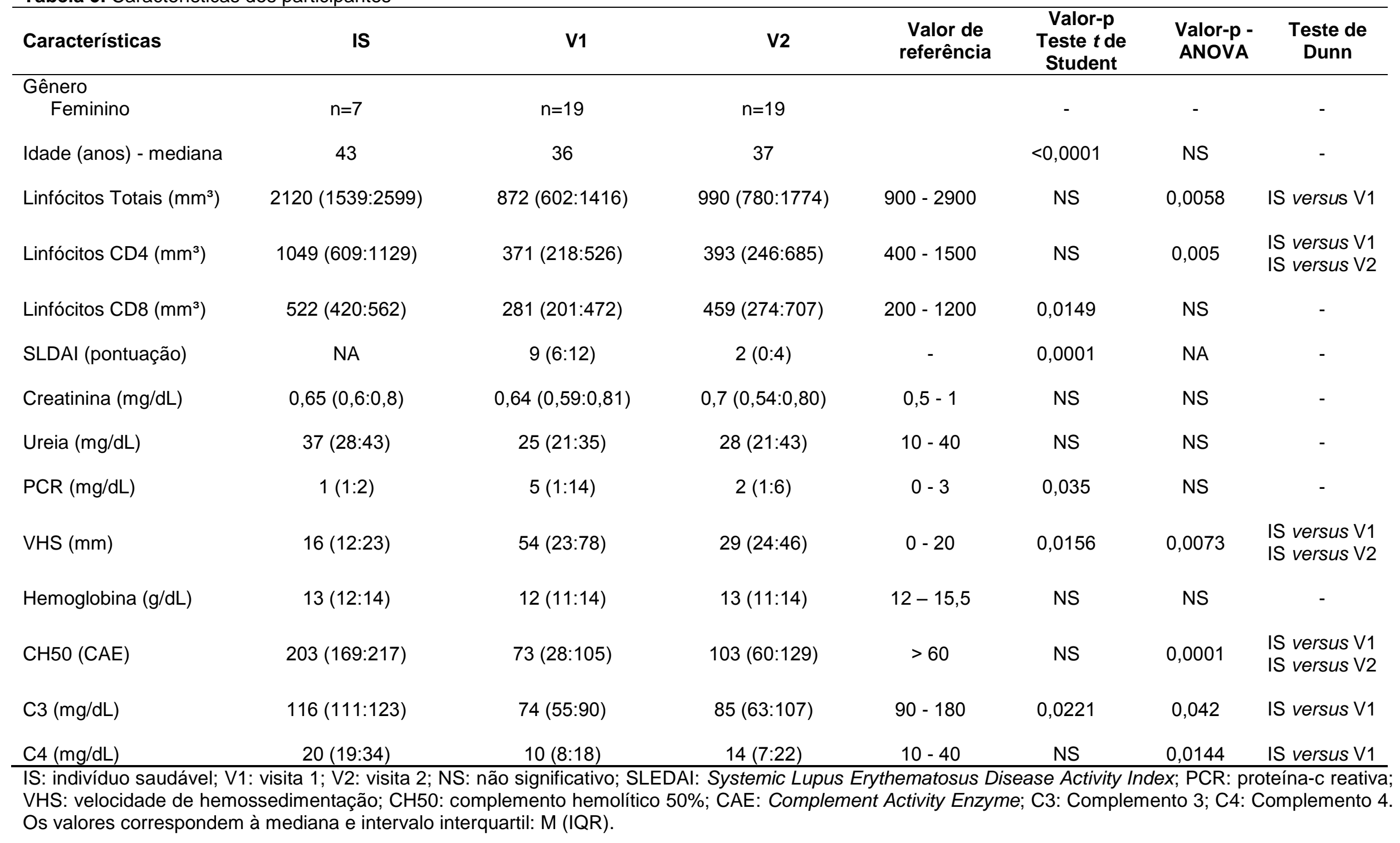


Para avaliar a função renal das participantes do estudo, nós utilizamos a razão de filtragem glomerular (Tabela 4) e a razão albumina-creatinina (Tabela 5). ${ }^{(48)}$

Tabela 4. Classificação da Razão de Filtração Glomerular em Doença Renal Crônica

\begin{tabular}{lcc}
\hline Categoria & $\begin{array}{c}\text { GFR }- \\
\text { mL/min/1,73m }\end{array}$ & Termos \\
\hline G1 & $\geq 90$ & Normal ou alta \\
G2 & $60-89$ & Levemente diminuída* \\
G3a & $45-59$ & Diminuição leve/moderada \\
G3b & $30-44$ & Diminuição moderada/severa \\
G4 & $15-29$ & Diminuição severa \\
G5 & $<15$ & Falha renal \\
\hline
\end{tabular}

GFR: glomerular filtration rate. ${ }^{*}$ Relativo aos níveis de adultos jovens.

Fonte: Traduzido de National Kidney Foundation. Available from: https://www.kidney.org/professionals/kdoqi/gfr_calculator

Tabela 5. Classificação de Albuminúria em Doença Renal Crônica

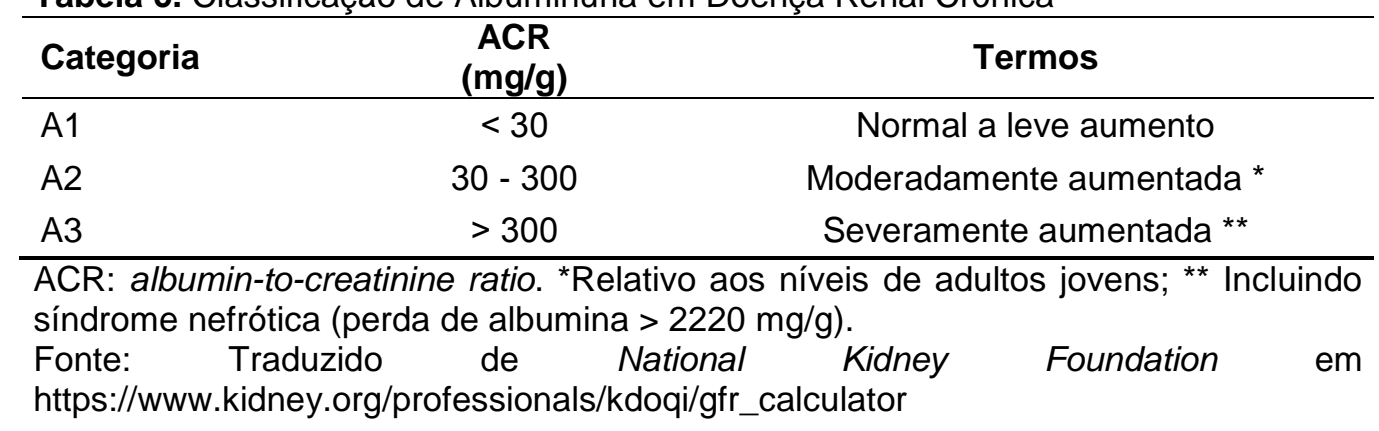

Nossas participantes não apresentaram nenhuma alteração relacionada à perda de função renal durante a fase ativa da doença ou na diminuição de atividade da doença (Tabela 6 e 7). 
Tabela 6. Classificação da função renal durante a fase ativa do Lúpus (V1)

\begin{tabular}{lccccc}
\hline ID & Idade & Sexo & Raça & Creatinina & $\begin{array}{c}\text { Classificação da } \\
\text { função renal }\end{array}$ \\
\hline$\# 02$ & 40 & $\mathrm{~F}$ & Branca & 1,3 & G3a/A1 \\
$\# 03$ & 37 & $\mathrm{~F}$ & Branca & 0,6 & $\mathrm{G} 1 / \mathrm{A} 1$ \\
$\# 07$ & 58 & $\mathrm{~F}$ & Branca & $\mathrm{ND}$ & $\mathrm{ND}$ \\
$\# 08$ & 41 & $\mathrm{~F}$ & Parda & 0,5 & $\mathrm{G} 1 / \mathrm{A} 1$ \\
$\# 09$ & 20 & $\mathrm{~F}$ & Branca & 0,59 & $\mathrm{G} 1 / \mathrm{A} 1$ \\
$\# 10$ & 35 & $\mathrm{~F}$ & Branca & 0,72 & $\mathrm{G} 1 / \mathrm{A} 1$ \\
$\# 12$ & 21 & $\mathrm{~F}$ & Branca & 0,6 & $\mathrm{G} 1 / \mathrm{A} 1$ \\
$\# 13$ & 25 & $\mathrm{~F}$ & Branca & 0,73 & $\mathrm{G} 1 / \mathrm{A} 1$ \\
$\# 14$ & 41 & $\mathrm{~F}$ & Branca & 1 & $\mathrm{G} 2 / \mathrm{A} 1$ \\
$\# 15$ & 19 & $\mathrm{~F}$ & Preta & 0,54 & $\mathrm{G} 1 / \mathrm{A} 1$ \\
$\# 16$ & 22 & $\mathrm{~F}$ & Branca & 0,6 & $\mathrm{G} 1 / \mathrm{A} 1$ \\
$\# 18$ & 40 & $\mathrm{~F}$ & Parda & 0,67 & $\mathrm{G} 1 / \mathrm{A} 1$ \\
$\# 19$ & 49 & $\mathrm{~F}$ & Branca & 0,85 & $\mathrm{G} 2 / \mathrm{A} 1$ \\
$\# 21$ & 44 & $\mathrm{~F}$ & Parda & 0,65 & $\mathrm{G} 1 / \mathrm{A} 1$ \\
$\# 23$ & 24 & $\mathrm{~F}$ & Branca & 0,58 & $\mathrm{G} 1 / \mathrm{A} 1$ \\
$\# 25$ & 26 & $\mathrm{~F}$ & Parda & 0,54 & $\mathrm{G} 1 / \mathrm{A} 1$ \\
$\# 26$ & 36 & $\mathrm{~F}$ & Branca & 0,79 & $\mathrm{G} 1 / \mathrm{A} 1$ \\
$\# 27$ & 36 & $\mathrm{~F}$ & Branca & 0,89 & G2/A1 \\
$\# 29$ & 18 & $\mathrm{~F}$ & Parda & 0,63 & G1/A1 \\
\hline
\end{tabular}

ID: identificação; ND : Não disponível.

Tabela 7. Classificação da função renal durante a baixa atividade/remissão do Lúpus (V2)

\begin{tabular}{cccccc}
\hline ID & Idade & Sexo & Raça & Creatinina & $\begin{array}{c}\text { Classificação da } \\
\text { função renal }\end{array}$ \\
\hline$\# 02$ & 41 & $F$ & Branca & 1,47 & G3b/A1 \\
$\# 03$ & 38 & $F$ & Branca & 0,5 & G1/A1 \\
$\# 07$ & 59 & $F$ & Branca & 0,7 & G1/A1 \\
$\# 08$ & 41 & $F$ & Parda & 1,2 & G2/A1 \\
$\# 09$ & 20 & $F$ & Branca & 0,44 & G1/A1 \\
$\# 10$ & 35 & $F$ & Branca & 0,7 & G1/A1 \\
$\# 12$ & 22 & $F$ & Branca & 0,79 & G1/A1 \\
$\# 13$ & 27 & $F$ & Branca & 0,7 & G1/A1 \\
$\# 14$ & 42 & $F$ & Branca & 1,03 & G2/A1 \\
$\# 15$ & 19 & $F$ & Preta & 0,52 & G1/A1 \\
$\# 16$ & 23 & $F$ & Branca & 0,5 & G1/A1 \\
$\# 18$ & 42 & $F$ & Parda & 0,64 & G1/A1 \\
$\# 19$ & 50 & $F$ & Branca & 0,7 & G1/A1 \\
$\# 21$ & 45 & $F$ & Parda & 0,6 & G1/A1 \\
$\# 23$ & 24 & $F$ & Branca & 0,62 & G1/A1 \\
$\# 25$ & 27 & $F$ & Parda & 0,54 & G1/A1 \\
$\# 26$ & 37 & $F$ & Branca & 0,8 & G1/A1 \\
$\# 27$ & 37 & $F$ & Branca & 0,7 & G1/A1 \\
$\# 29$ & 19 & $F$ & Parda & 0,8 & G1/A1 \\
\hline ID: identificação & & & &
\end{tabular}




\subsection{Frequência de linfócitos B e suas subpopulações em pacientes com lúpus eritematoso sistêmico}

Nós analisamos a frequência de linfócitos B e subpopulações na V1 e na V2 de pacientes com LES, e entre os dois grupos não observamos nenhuma diferença estatística, mostrando que o perfil dessas células não sofrem alterações em relação à atividade ou baixa atividade do LES. Total de linfócitos $B$ [V1: $M=30$ IQR (28:49) V2: $M=26$ IQR (14:60)] (Figura 4B).
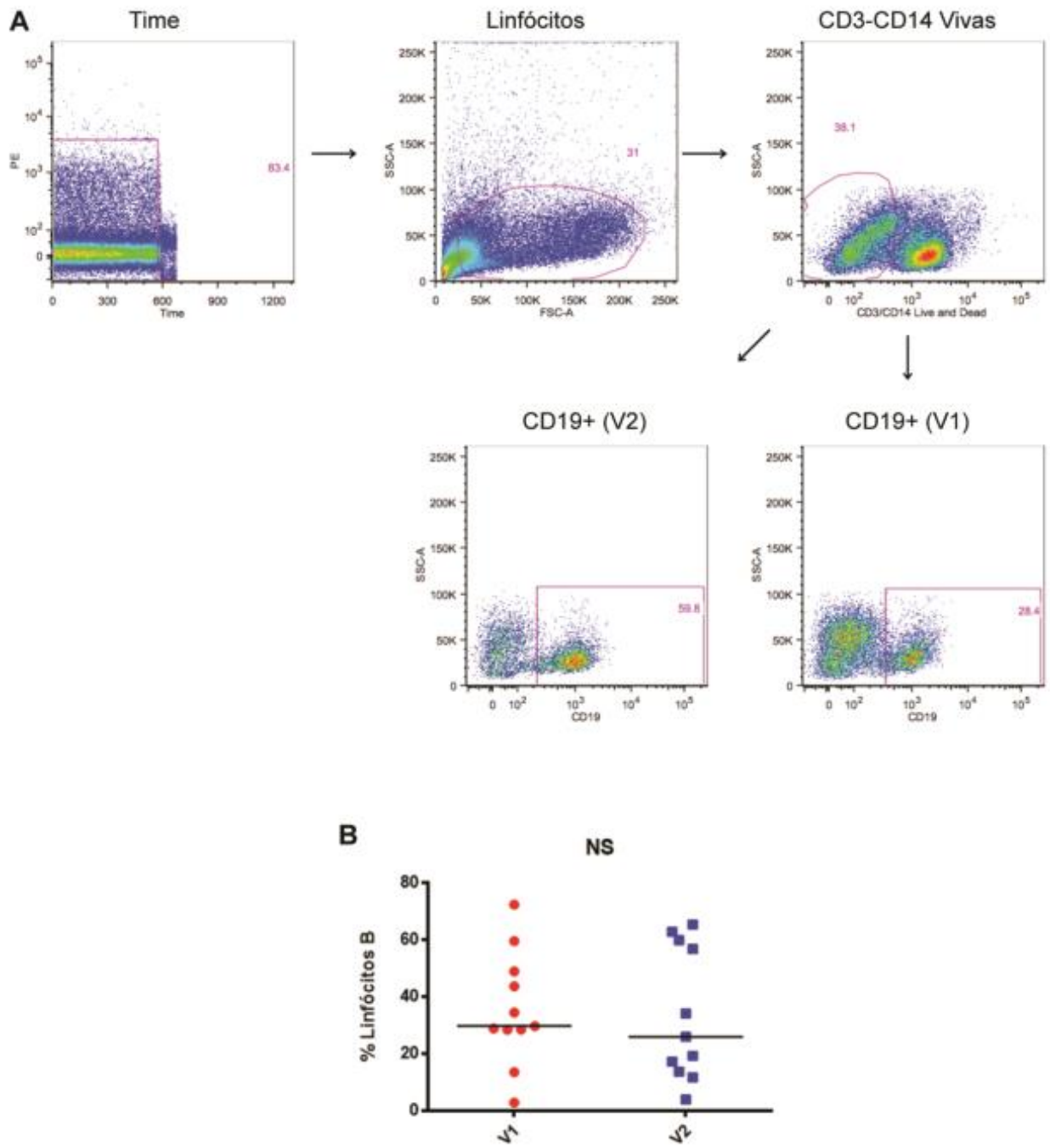

A) Da esquerda para direita: Seleção do gate de tempo a partir da dispersão de PE x Time; seleção de linfócitos a partir da dispersão de eventos por SSC-A x FSC-A; seleção de linfócitos vivos e negativos para CD3 e CD14 através da dispersão de eventos por CD3/CD14 x LIVE/DEAD TM, seleção de linfócitos B por SSC-A por CD19. B) Porcentagem de linfócitos $B(C D 19+)$ em pacientes com LES ativo (V1) e LES em baixa atividade (V2). A fenotipagem dos linfócitos $B$ foi realizada através da técnica de citometria de fluxo. V1 $n=11 ; \mathrm{V} 2 \mathrm{n}=11$; valor atribuído para $p \leq 0,05$.

Figura 4. Estratégia de análise de linfócitos $B$ total e porcentagem de linfócitos $B$ 
Os linfócitos B derivados do centro germinativo dos pacientes com LES ativo e em baixa atividade foram analisados através de uma estratégia utilizada para verificação de linfócitos $B$ em tonsilas. Não houve diferenças estatísticas em relação à frequência de linfócitos $\mathrm{B}$ derivados do centro germinativo durante a atividade e baixa atividade do LES [V1: $M=42$ IQR (15:53) V2: $M=42$ IQR (32:56)] (Figura 5B).
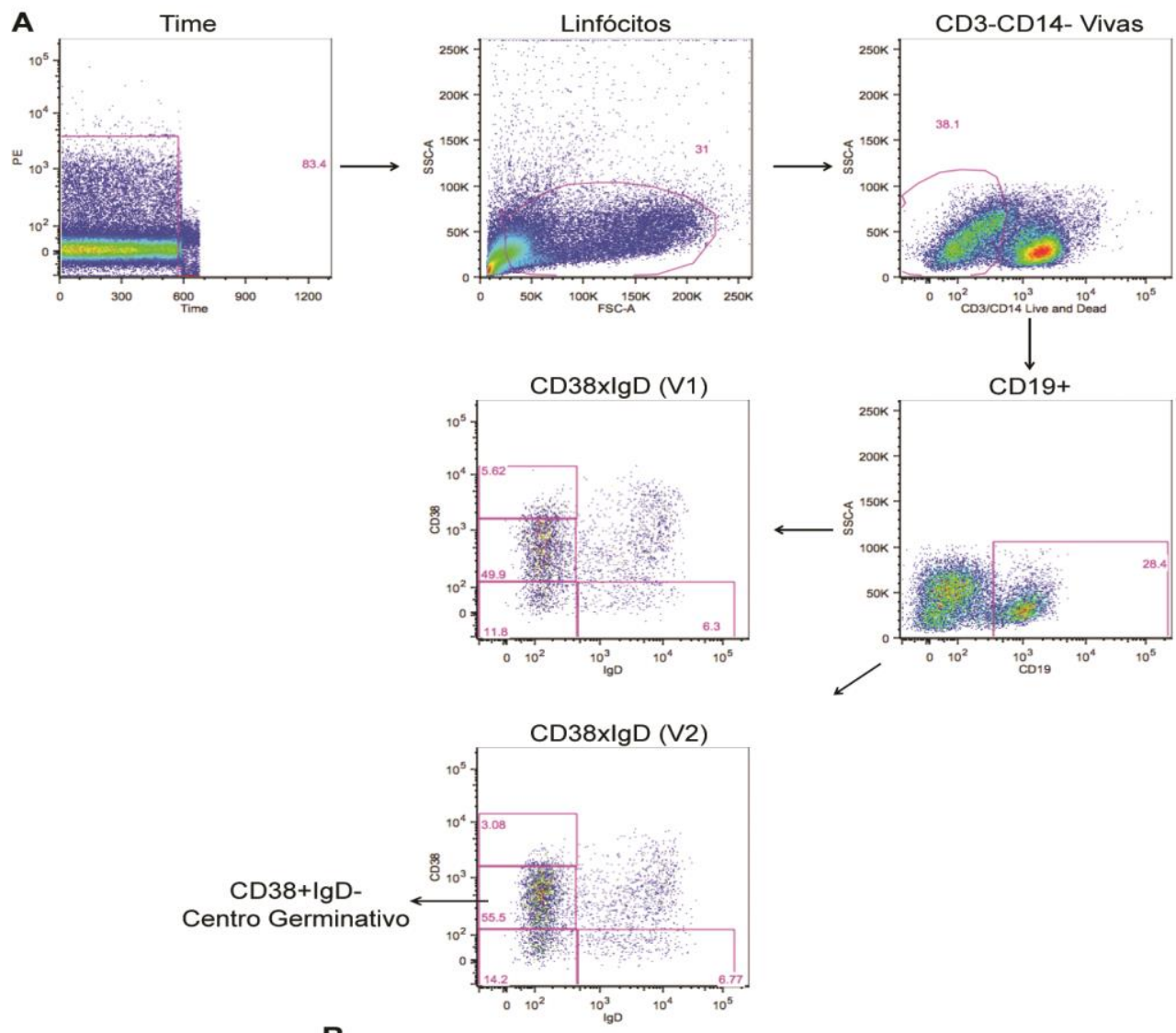

B

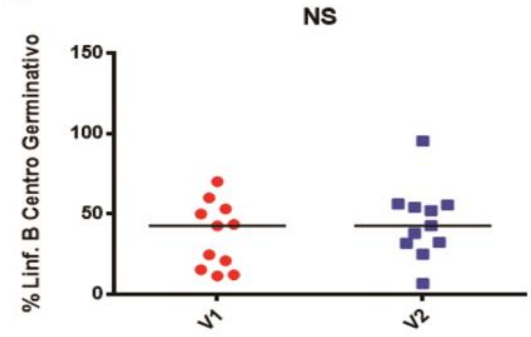

A) Da esquerda para direita: Seleção do gate de tempo a partir da dispersão de PE x Time; seleção de linfócitos a partir da dispersão de eventos por SSC-A x FSC-A; seleção de linfócitos vivos e negativos para CD3 e CD14 através da dispersão de eventos por CD3/CD14 x LIVE/DEAD ${ }^{\mathrm{TM}}$, seleção de linfócitos B por SSC-A por CD19, seleção de linfócitos $\mathrm{B}$ do centro germinativo pela dispersão de eventos por CD38 x $\operatorname{lgD}$. B) Porcentagem de linfócitos $B$ do centro germinativo (CD19+ CD38+ lgD-) em pacientes com LES ativo (V1) e LES em baixa atividade (V2). A fenotipagem dos linfócitos $B$ foi realizada através da técnica de citometria de fluxo. V1 $n=11$; V2 $n=11$; valor atribuído para $p \leq 0,05$.

Figura 5. Estratégia de análise de linfócitos $B$ do centro germinativo e porcentagem de linfócitos B do centro germinativo 
Analisamos também 0 perfil de linfócitos $B$ de memória dos pacientes com LES ativo e em baixa atividade, a partir da análise das proteínas expressas na superfície CD21 x CD27. Essa estratégia nos possibilitou analisar linfócitos B Intermediate Memory [V1: $\mathrm{M}=49$ IQR (14:65) V2: $\mathrm{M}=47$ IQR (13:59)] (Figura 6B) linfócitos B Resting Memory [V1: M = 9 IQR (5:21) V2: M = 15 IQR (2:30)] (Figura 6C), linfócitos B Activated Memory [V1: M = 3 IQR (1:5) V2: M = 3 IQR (1:6)] (Figura 6D) e os linfócitos B Tissue-like Memory [V1: $M=28$ IQR (23:78) V2: $M=20$ IQR (14:84)] (Figura 6E). Não observamos diferenças significativas dessas subpopulações entre o LES ativo e em baixa atividade. 

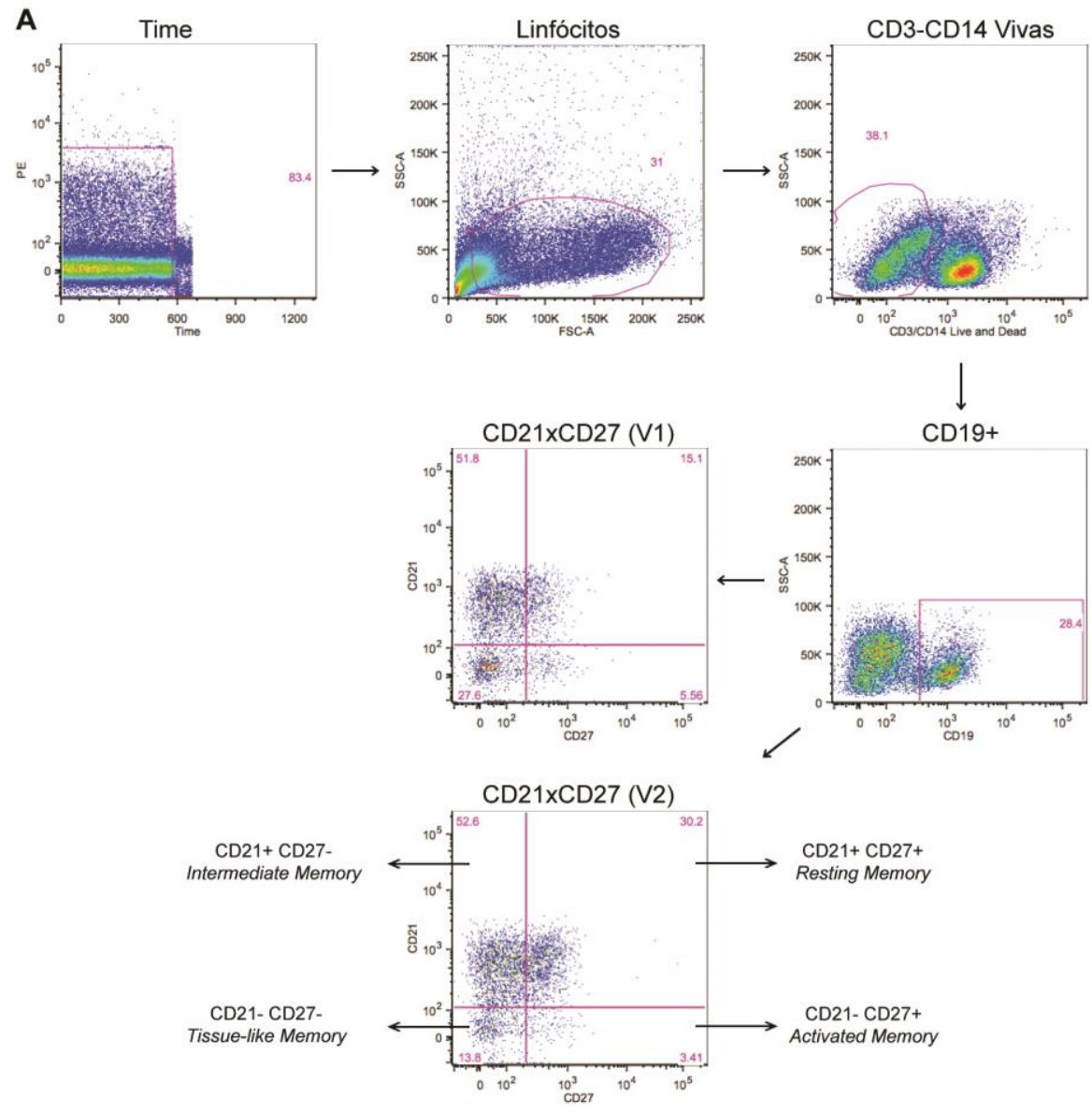

B

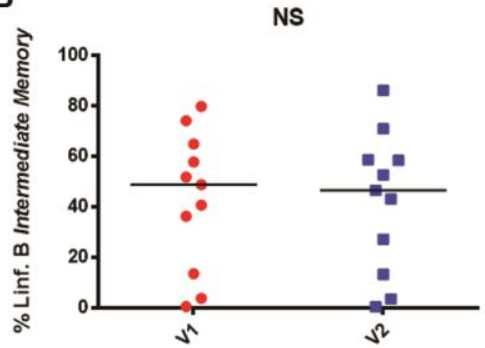

D

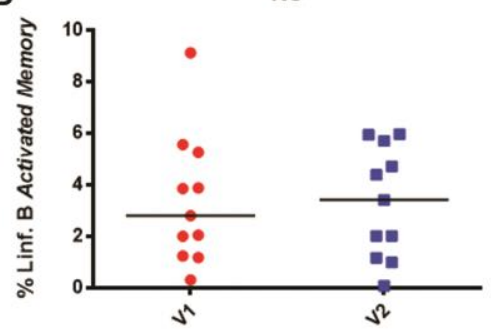

C

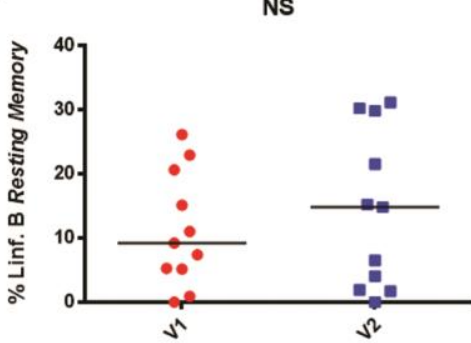

$\mathbf{E}$

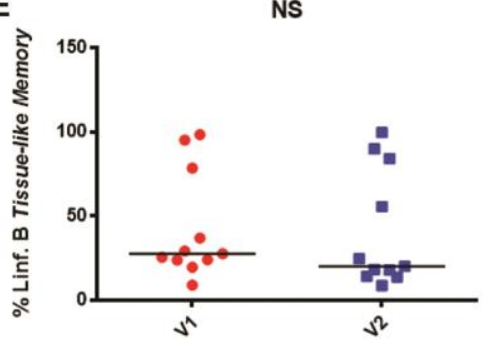

A) Da esquerda para direita: seleção do gate de tempo a partir da dispersão de PE x Time; seleção de linfócitos a partir da dispersão de eventos por SSC-A x FSC-A; seleção de linfócitos vivos e negativos para CD3 e CD14 através da dispersão de eventos por CD3/CD14 x LIVE/DEAD ${ }^{\mathrm{TM}}$, seleção de linfócitos B por SSC-A por CD19, seleção de linfócitos B pela dispersão de eventos por CD21 x CD27. B) Porcentagem de linfócitos B Intermediate Memory (CD19+ CD21+CD27-). C) Porcentagem de linfócitos B Resting Memory (CD19+ CD21+ CD27+). D) Porcentagem de linfócitos B Activated Memory (CD19+ CD21- CD27+). E) Porcentagem de linfócitos B Tissue-like Memory (CD19+ CD21- CD27-). Pacientes com LES ativo (V1) e LES em baixa atividade (V2). A fenotipagem dos linfócitos $B$ foi realizada através da técnica de citometria de fluxo. V1 $n=11 ; V 2 n=11$; valor atribuído para $p \leq 0,05$.

Figura 6. Estratégia de análise de linfócitos B CD21 x CD27 e porcentagem das subpopulações 
Através da análise de linfócitos B por CD27 x lgD, nós observamos a frequências de plasmócitos [V1: $M=8$ IQR (5:24) V2: $M=15$ IQR (2:29)] (Figura 7B), linfócitos B Pré-switch Memory [V1: M = 4 IQR (2:7) V2: M = 5 IQR (3:7)] (Figura 7C), linfócitos B Naive [V1: $M=50$ IQR (23:67) V2: $M=31$ IQR (18:59)] (Figura 7D) e linfócitos B de memória [V1: M = 37 IQR (26:47) V2: $M=40$ IQR (28:54)] (Figura 7E). Entre os pacientes com LES em atividade e baixa atividade, não foram observadas diferenças significativas. 

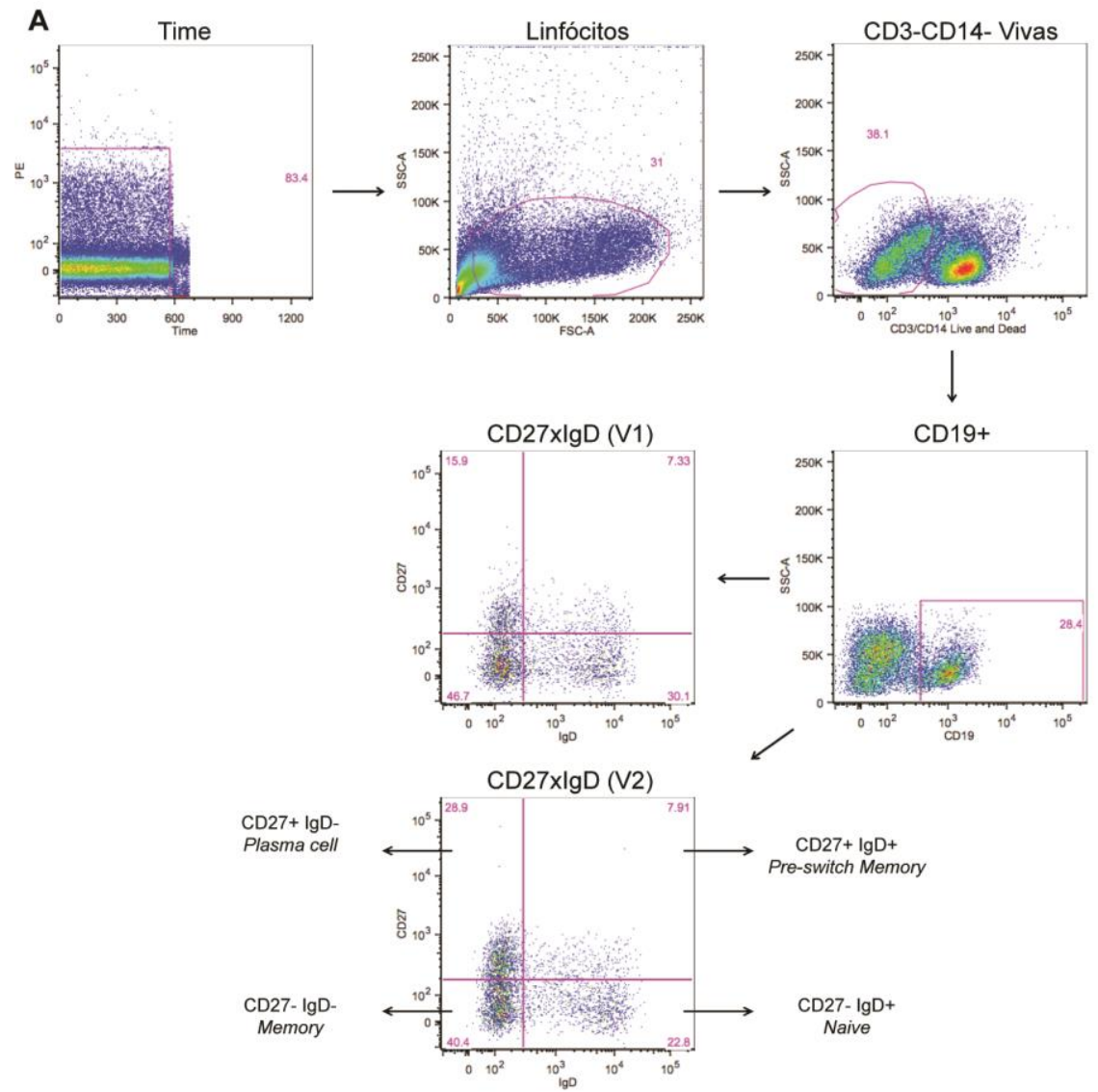

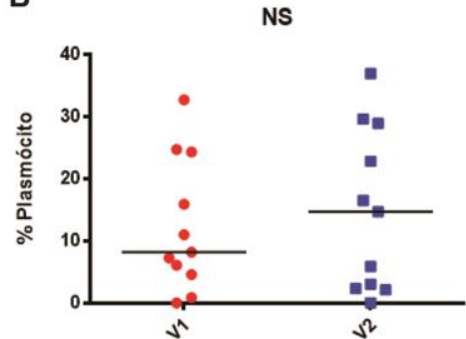

D

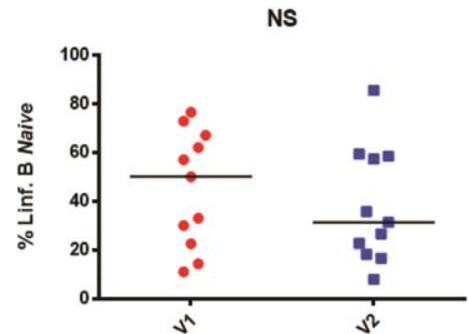

C

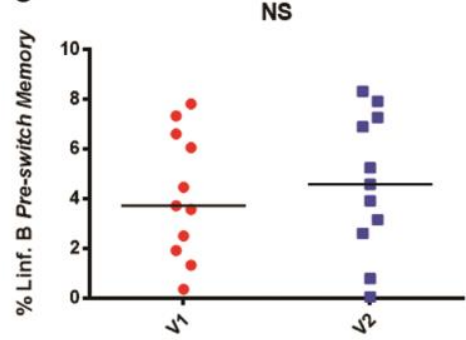

E

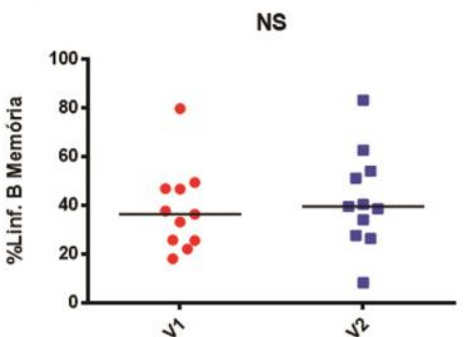

A) Da esquerda para direita: seleção do gate de tempo a partir da dispersão de PE x Time; seleção de linfócitos a partir da dispersão de eventos por SSC-A x FSC-A; seleção de linfócitos vivos e negativos para CD3 e CD14 através da dispersão de eventos por CD3/CD14 x LIVE/DEAD TM , seleção de linfócitos B por SSC-A por CD19, seleção de linfócitos B pela dispersão de eventos por CD27 x lgD. B) Porcentagem de linfócitos B Plasma cell (CD19+ CD27+ IgD-). C) Porcentagem de linfócitos B Preswitch Memory (CD19+ CD27+ IgD+). D) Porcentagem de linfócitos B Naive (CD19+ CD27- IgD+). E) Porcentagem de linfócitos B de memória (CD19+ CD27- IgD-). Pacientes com LES ativo (V1) e LES em baixa atividade (V2). A fenotipagem dos linfócitos $B$ foi realizada através da técnica de citometria de fluxo. V1 $n=11$; V2 $n=11$; valor atribuído para $p \leq 0,05$.

Figura 7. Estratégia de análise de linfócitos B CD21 x CD27 e porcentagem das subpopulações 
Verificamos também a média de intensidade de fluorescência (MFI) do marcador de linfócito $B$ IgM entre os pacientes com LES ativo e após a remissão, e não encontramos diferenças significativas entre os dois grupos [V1: $M=39$ IQR (75:1686) V2: $M=-83$ IQR (-111:118)] (Figura 8).

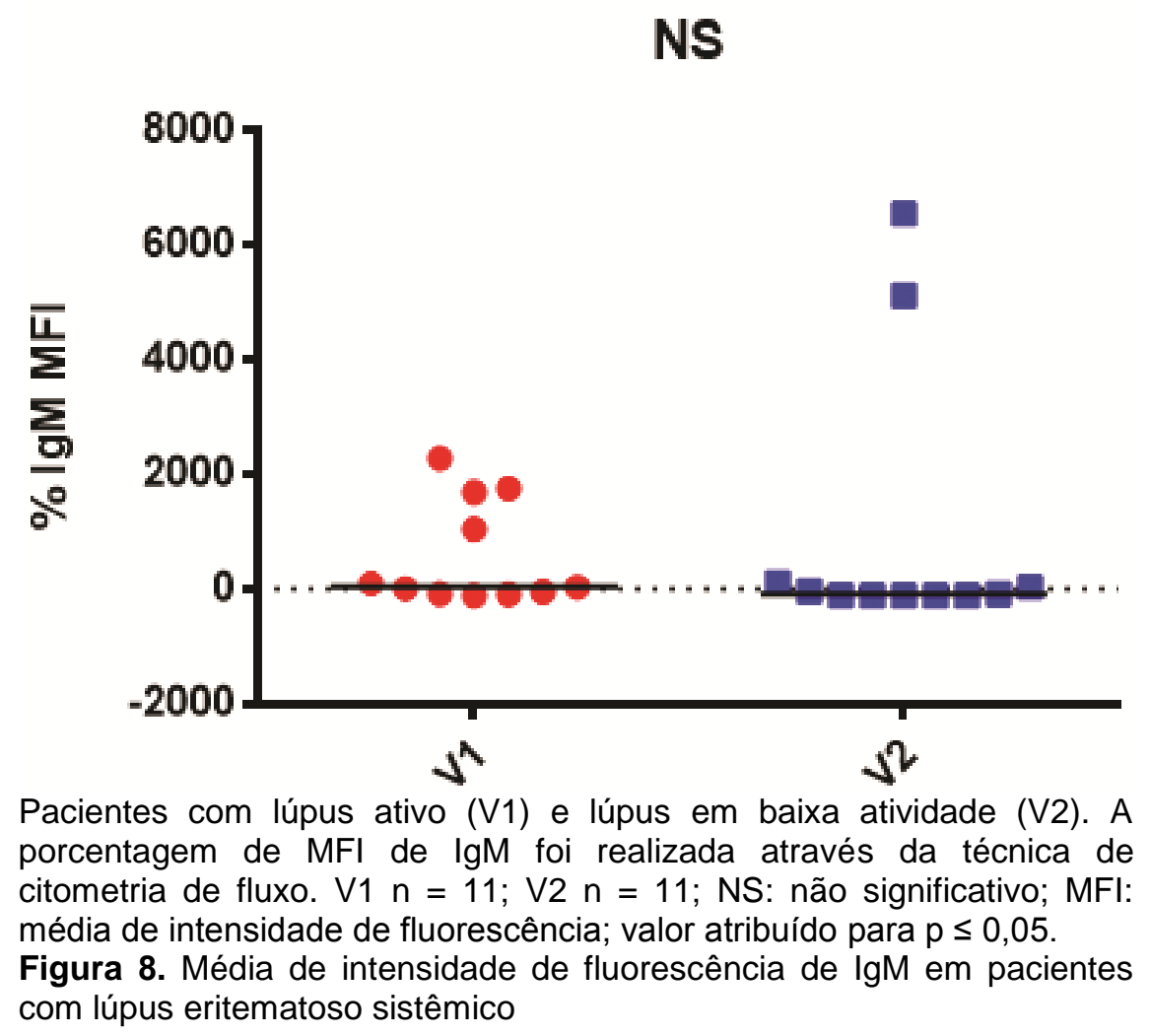

Observamos uma correlação positiva entre linfócitos B de memória e os linfócitos $B$ derivados do centro germinativo entre as duas visitas $(\mathrm{V} 1: r=0,83 ; p=$ 0,0013. O V2: $r=0,76 ; p=0,0086$ ) (Figura 9 A e B). Esses resultados nos mostram que durante a fase ativa do LES, os pacientes apresentam um perfil de linfócitos ativos, e estas células são provenientes do GC. E no momento de baixa atividade do LES, há diminuição dos linfócitos $B$ derivados do centro germinativo e aumento do número de linfócitos de memória, representando dessa forma a inatividade da doença. 

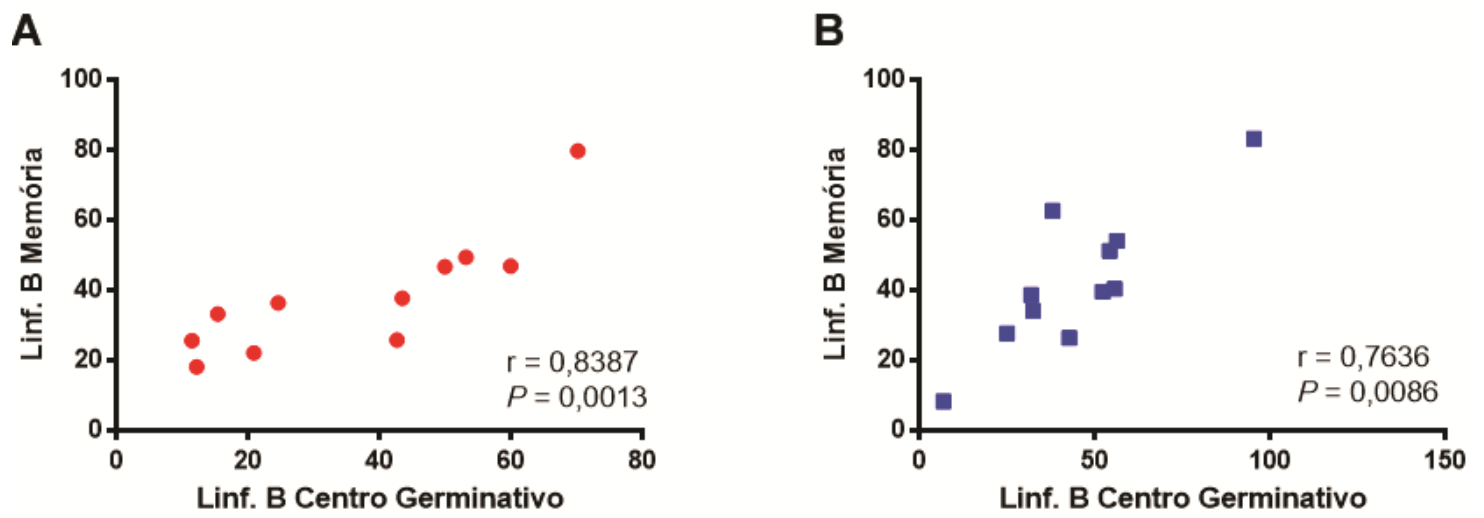

A) Pacientes com LES ativo (V1). B) Pacientes com LES em baixa atividade (V2). Foi utilizada Correlação de Pearson ou Spearman. V1 $n=11$; V2 $n=11$; valor atribuído para $p \leq 0,05$.

Figura 9. Correlação entre linfócitos $B$ de memória e linfócitos $B$ do centro germinativo em pacientes com lúpus eritematoso sistêmico

Corroborando com este achado, encontramos resultados significativos quando realizamos correlação entre MFI de IgM e linfócitos B derivados do centro germinativo na fase ativa do LES (V1: $r=-0,72 ; p=0,0144$. V2: $r=-0,52 ; p=$ 0,0995 ) (Figura $10 \mathrm{~A}$ e B). Esse dado sugere que os pacientes com LES ativo possuem maior quantidade de linfócitos autorreativos, perfil que é visto nesta patologia.
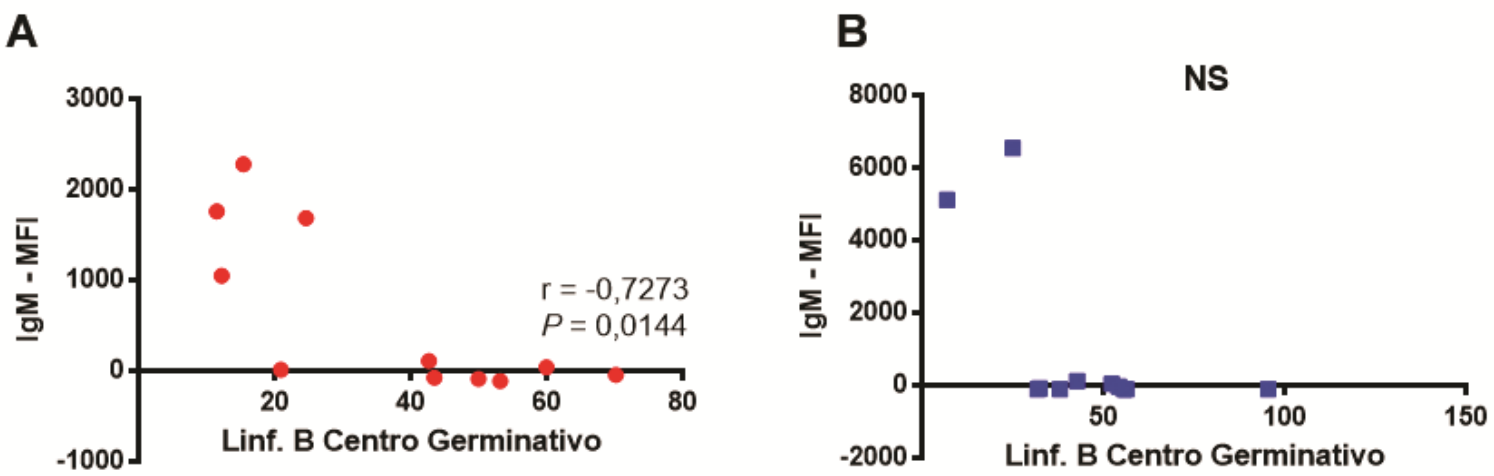

A) Pacientes com LES ativo (V1). B) Pacientes com LES em baixa atividade (V2). Foi utilizada Correlação de Pearson ou Spearman. V1 $n=11$; V2 $n=11$; valor atribuído para $p \leq 0,05$.

Figura 10. Correlação entre média de intensidade de fluorescência de $\operatorname{lgM}$ e linfócitos $B$ do centro germinativo em pacientes com lúpus eritematoso sistêmico

Quando comparamos os resultados de linfócitos B e subpopulações de pacientes com LES ativo e em baixa atividade com indivíduos saudáveis, vemos que o perfil de linfócitos $B$ [IS: $M=48$ IQR (46:55) V1: $M=30$ IQR (28:49) V2: $M=26$ IQR (14:60)], Resting Memory [IS: $M=12$ IQR (10:21) V1: $M=9$ IQR (5:21) V2: $M=15$ IQR (2:30)] Activated Memory [IS: M = 1 IQR (1:2) V1: $M=3$ IQR (1:5) V2: $M=3$ IQR 
(1:6)] e plasmócitos [IS: M = 7 IQR (6: 12) V1: M = 8 IQR (5:24) V2: M = 15 IQR (2:29)], não apresentaram diferenças significativas entre V1, V2 e IS (dado não mostrado).

A subpopulação de linfócitos $B$ derivados do centro germinativo demonstrou diferenças estatísticas entre indivíduos saudáveis e LES ativo, e indivíduos saudáveis e LES em baixa atividade [IS: $M=8$ IQR (6: 11) V1: $M=43$ IQR (15:53) V2: $M=42$ IQR (32:56)] (Figura 11A). Quando comparamos LES ativo e baixa atividade com indivíduos saudáveis, das subpopulações de linfócitos B CD21 x CD27, encontramos resultados relevantes de Intermediate Memory [IS: $\mathrm{M}=81$ IQR (73:86) V1: $M=49$ IQR (14:65) V2: $M=47$ IQR (13:59)] e Tissue-like Memory [IS: $M=5$ IQR (2:5) V1: $M=28$ IQR (24:78) V2: $M=20$ IQR (14:84)] (Figura 11B e C). Observamos diferenças significativas entre os grupos das subpopulações Pre-switch Memory [IS: M = 8 IQR (7:9) V1: $M=4$ IQR (2:7) V2: $M=5$ IQR (3:7)], linfócitos B Naive [IS: $M=70$ IQR (66:78) V1: $M=50$ IQR (23:67) V2: $M=31$ IQR (18:59)] e linfócitos $B$ de memória [IS: $M=10$ IQR (9:16) V1: $M=36$ IQR (26:47) V2: $M=40$ IQR (28:54)] (Figura 11D $\mathrm{F})$. 
A

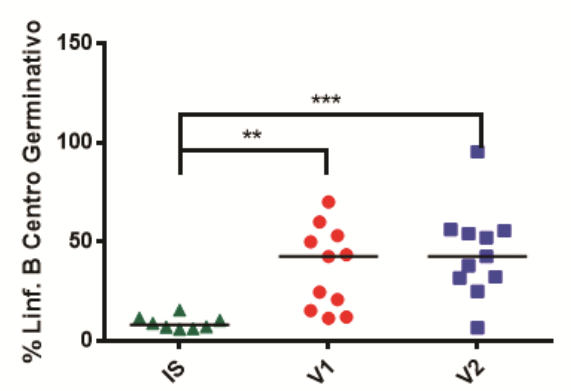

B

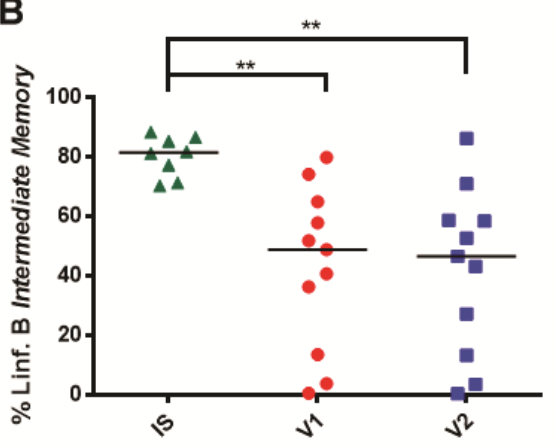

D

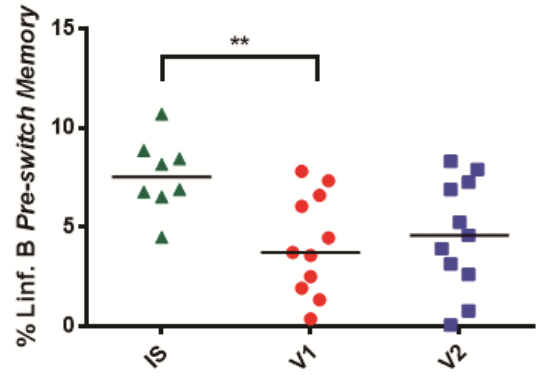

C

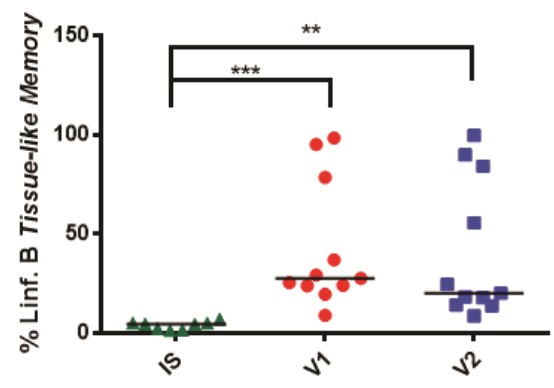

E

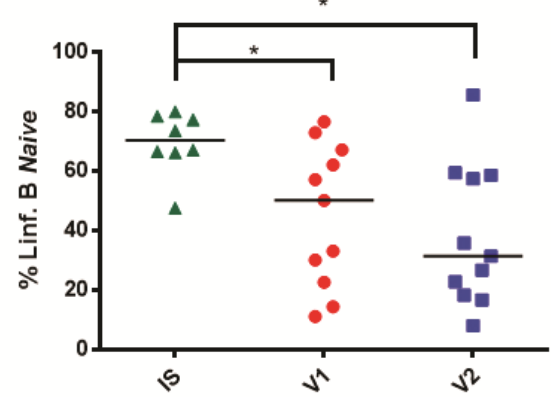

$\mathbf{F}$

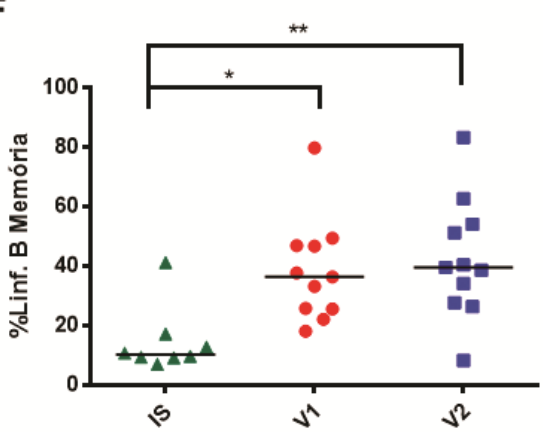

A) Porcentagem de linfócitos $B$ do centro germinativo (CD19+ CD38+ IgD-). B) Porcentagem de linfócitos B Intermediate Memory (CD19+ CD21+ CD27-). C) Porcentagem de linfócitos B Tissue-like Memory (CD19+ CD21- CD27-). D) Porcentagem de linfócitos B Pre-switch Memory (CD19+ CD27+ IgD+). E) Porcentagem de linfócitos $B$ Naive (CD19+ CD27- IgD+). F) Porcentagem de linfócitos B de memória (CD19+ CD27- IgD-). Indivíduos saudáveis (IS), pacientes com LES ativo (V1) e LES em baixa atividade (V2). A fenotipagem dos subgrupos de linfócitos $B$ foi realizada através da técnica de citometria de fluxo. IS $n=8 ; \mathrm{V} 1 \mathrm{n}=11$; $\mathrm{V} 2 \mathrm{n}=11$; valor atribuído para $\mathrm{p} \leq 0,05$.

Figura 11. Frequência de subpopulações de linfócitos $B$ em pacientes com lúpus eritematoso sistêmico e indivíduos saudáveis 


\subsection{Frequência de ILC2 em pacientes com lúpus eritematoso sistêmico}

Não foi observada diferença entre pacientes e IS na frequência de células ILC2 [V1: M = 0,54 IQR (0,45:0,92) V2: M=0,24 IQR (0:0,73)] Isto nos mostrou que a frequência das ILC2 do sangue, não se alteram em relação ao estado da doença (Figura 12B). 

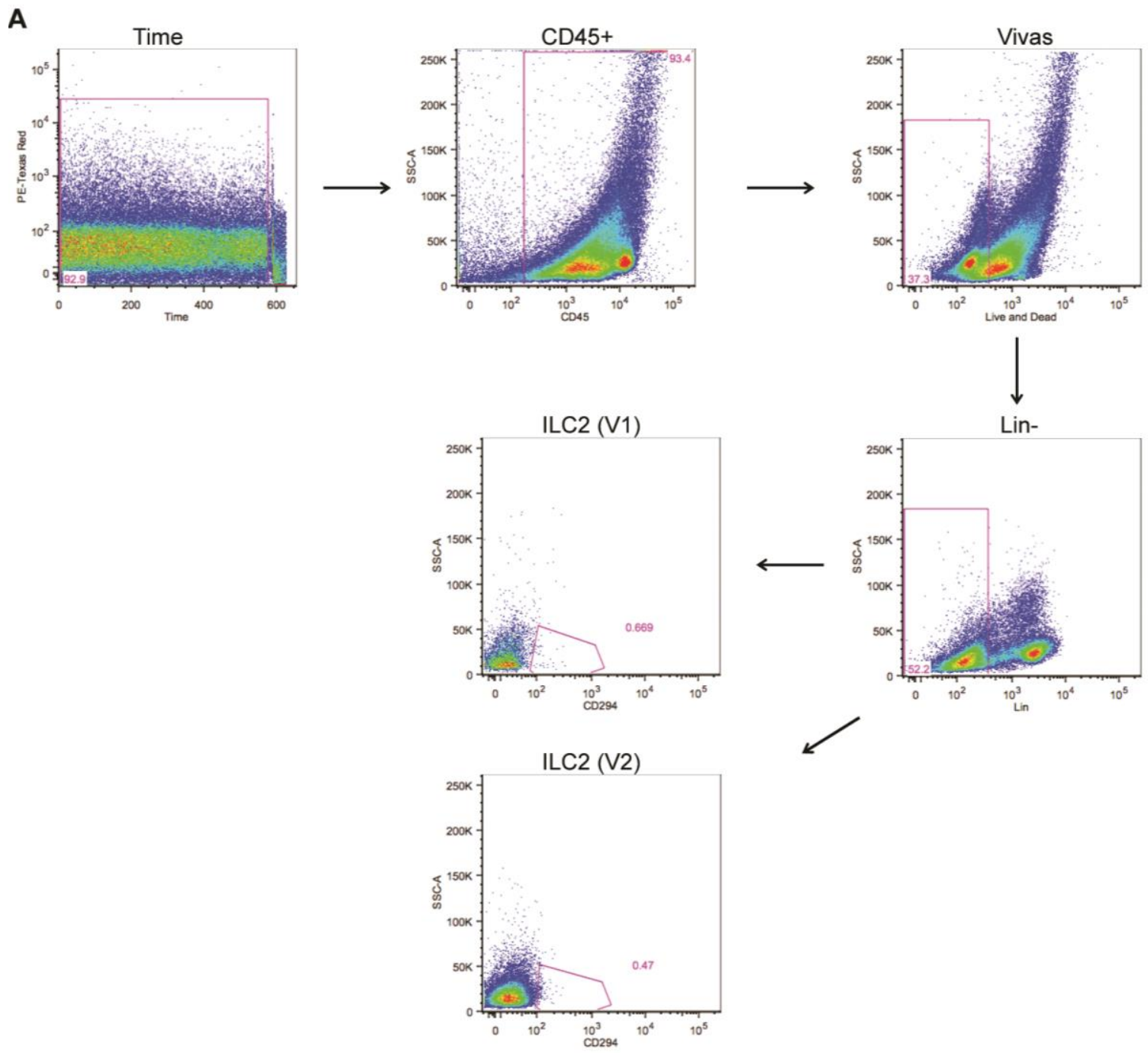

B

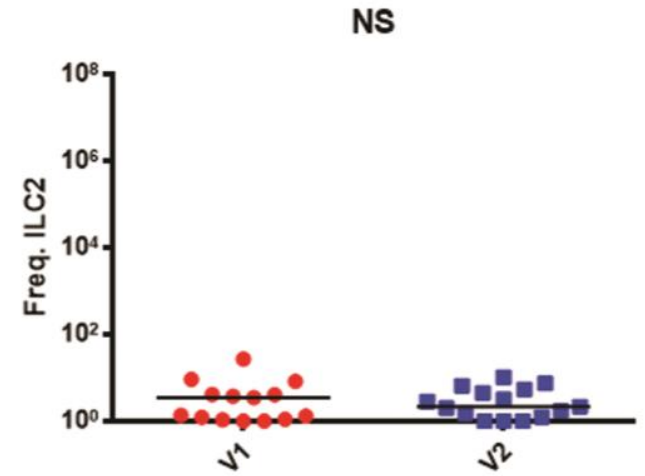

A) Da esquerda para direita: Seleção do gate de tempo a partir da dispersão de PE-Texas Red $\mathrm{x}$ Time; seleção de leucócitos a partir da dispersão de eventos por SSC-A x CD45+; seleção das células vivas por SSC-A $\times$ LIVE/DEAD ${ }^{\mathrm{TM}}$, seleção de células de linhagem negativa a partir da dispersão de eventos por SSC-A x Lin; e seleção de ILC2 a partir da dispersão de eventos por CD45+ CRTH2+. B) Porcentagem de ILC2 (Lin- CD45+ CRTH2+). Pacientes com LES ativo (V1) e LES em baixa atividade (V2). A fenotipagem das ILCs foi realizada através da técnica de citometria de fluxo. V1 $n=15 ; \mathrm{V} 2 \mathrm{n}=15$; valor atribuído para $\mathrm{p} \leq 0,05$.

Figura 12. Estratégia de análise de imunofenotipagem e frequência de células linfoides inatas tipo 2 no sangue 


\subsection{Análise funcional das ILC2 em pacientes com lúpus eritematoso sistêmico}

Para saber se a funcionalidade das ILC2 apresentava algum tipo de alteração nos pacientes com LES, nós realizamos um teste funcional onde estimulamos as células com PMA e lonomicina por aproximadamente 16 horas. Após o período de incubação, prosseguimos com a fenotipagem e marcação das citocinas IL-4 e IL-13. A frequência das ILC2 entre os pacientes com LES em atividade e os pacientes em baixa atividade, não demonstrou resultados significativos, portanto o estímulo de PMA e lonomicina não alterou a fenotipagem dessas células [V1: $M=0,16 \operatorname{IQR}(0,06: 0,53)$ V2: $M=0,44 \operatorname{IQR}(0,23: 0,56)]$ (Figura 13B).

Quando analisamos os resultados das citocinas IL-4 [V1: $M=0,83$ $\operatorname{IQR}(0: 1,9)$ V2: $M=1,21 \operatorname{IQR}(0,43: 3,5)]$ e IL-13 [V1: $M=0,09 \operatorname{IQR}(0: 0,93)$ V2: $M=0,3$ IQR $(0: 0,71)]$ após o estímulo, não observamos aumento na frequência de secreção das citocinas independente do estado da doença (Figura 13C). 
A
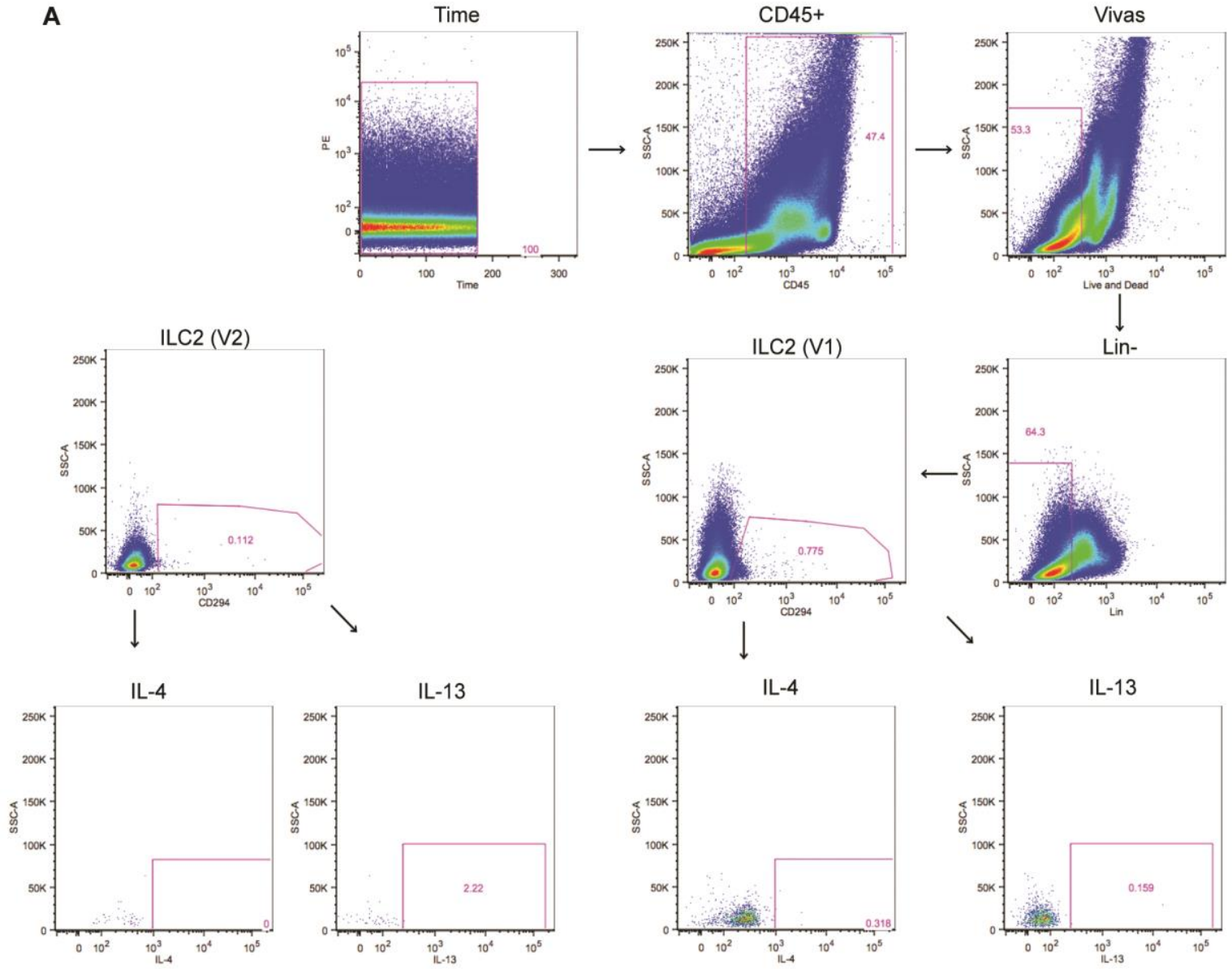

B

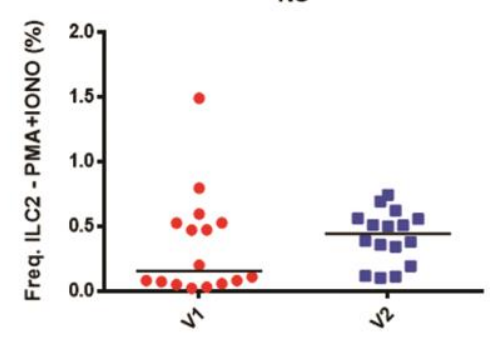

C

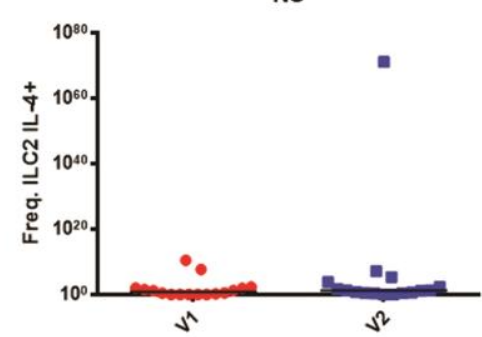

D

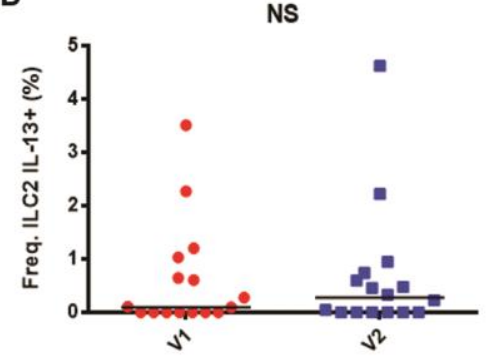

A Da esquerda para direita: Seleção do gate de tempo a partir da dispersão de PE $x$ Time; seleção de leucócitos a partir da dispersão de eventos por SSC-A x CD45+; seleção das células vivas por SSC-A x LIVE/DEAD ${ }^{\mathrm{TM}}$, seleção de células de linhagem negativa a partir da dispersão de eventos por SSC-A x Lin; e seleção de ILC2 a partir da dispersão de eventos por CD45+ CRTH2+, seleção das ILC2 IL-4+ e ILC2 IL-13+. B) Porcentagem de ILC2 (Lin- CD45+ CRTH2+) estimulado com PMA e lonomicina por aproximadamente 16 horas. C) Porcentagem de ILC2 IL4+ e ILC2 IL-13+. Pacientes com LES ativo (V1) e LES em baixa atividade (V2). A fenotipagem das ILCs e das citocinas foi realizada através da técnica de citometria de fluxo. V1 $n=16$; V2 $n=$ 16; valor atribuído para $p \leq 0,05$.

Figura 13. Estratégia de análise de ensaio funcional de células linfoides inatas tipo 2 e frequência de IL-4 e IL-13 secretadas por células linfoides inatas tipo 2 
Não havendo diferenças estatísticas entre LES ativo e LES em baixa atividade, comparamos os perfis apresentados pelos pacientes com o perfil de ILC2 de indivíduos saudáveis (IS) [IS: $M=0,23$ IQR $(0,09: 0,41)$ V1: $M=0,54 \operatorname{IQR}(0,04: 0,92)$ V2: $M=0,33$ IQR $(0,1: 0,73)]$ e foi possível observar que o perfil das ILC2 no LES é igual ao perfil dos IS, independentemente do estado da doença (Figura 14).

\section{NS}

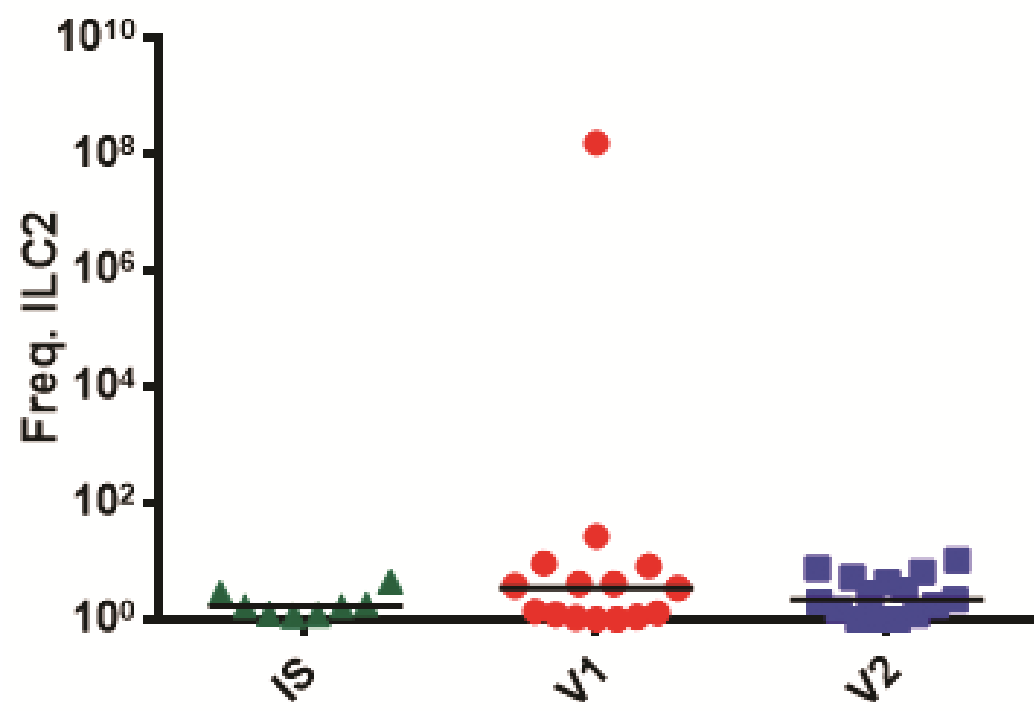

Indivíduos saudáveis (IS), pacientes com LES ativo (V1) e LES em baixa atividade (V2). A fenotipagem das ILCs foi realizada através da técnica de citometria de fluxo. IS $n=8 ; V 1 n=15 ;$ V2 $n=15$; valor atribuído para $\mathrm{p} \leq 0,05$.

Figura 14. Porcentagem de células linfoides inatas tipo 2 entre pacientes com lúpus eritematoso sistêmico ativo, pacientes em baixa atividade e indivíduos saudáveis 


\section{DISCUSSÃO}

O LES é uma doença autoimune, caracterizada por inflamação sistêmica crônica que oscila entre períodos de atividade e remissão. A exata etiologia dessa doença permanece desconhecida, e a principal característica da doença é a ativação exacerbada do sistema imunológico que gera aumento na produção de autoanticorpos e secreção de citocinas inflamatórias. ${ }^{(1)}$ No decorrer dos anos, pesquisadores identificaram marcadores que indicam pré-disposição a desenvolver o LES e marcadores de atividade da doença, por exemplo, anti-dsDNA, anti-Sm e diminuição dos níveis séricos das frações de complemento C3 e C4, respectivamente. ${ }^{(17)}$

Utilizamos os critérios clínicos do SLICC para analisar os dados clínicos das participantes da pesquisa ${ }^{(17)}$, e nossos achados mostram claramente que as participantes estavam com o LES ativo durante a primeira visita, pois apresentavam SLEDAI alto e diminuição da fração de complemento $C 3$, e quando analisamos os dados da segunda visita, notamos diminuição do SLEDAI e aumento de C3. O sistema complemento participa tanto da imunidade inata, quanto da imunidade adaptativa, ele é constituído por cerca de 30 proteínas diferentes, que podem ser solúveis ou estarem expressas nas membranas celulares. O sistema complemento tem diversas funções dentre elas, ativação de linfócitos $B$ e destruição de imunocomplexos, formações de $\lg \mathrm{M}$ e $\lg \mathrm{G}$ ligados a um ou mais epítopos simultaneamente. ${ }^{(49)}$

Além disso, foi observada também a diminuição do número absoluto de linfócitos T CD8 ${ }^{+}$na fase ativa do LES (V1). Wouters et al. encontraram resultados semelhantes aos nossos em relação aos linfócitos T CD8 ${ }^{+}$, neste estudo o grupo descreve que a diminuição desses linfócitos está relacionada à ativação dos mesmos durante a atividade do LES, e que provavelmente esses linfócitos estariam migrando para sítios inflamatórios, mas principalmente nas lesões cutâneas. ${ }^{(50)}$

Diversos trabalhos estudam a participação dos linfócitos B em doenças autoimunes, inclusive no LES, pois essas células são responsáveis pela produção de autoanticorpos que desempenham papel importante na patogênese. ${ }^{(51,52)}$ Nossos dados mostraram que o perfil dos linfócitos B e subpopulações em indivíduos com LES ativo e em baixa atividade são equivalentes, sugerindo assim que este perfil possa ser uma característica do LES nessa população. Mas pudemos observar que há 
aumento na frequência de linfócitos $B$ derivados do centro germinativo nos pacientes com LES em comparação com os indivíduos saudáveis. São classificados como linfócitos GC, linfócitos B ativados por linfócitos T-helpers localizados nos GC de órgãos linfoides secundários, como por exemplo, tonsilas. ${ }^{(53)}$ Um fato importante que ocorre no GC é a hipermutação somática, fazendo com que ocorra a mudança de afinidade do BCR, em indivíduos saudáveis, essa mudança será feita para que os linfócitos sejam capazes de reagir a um antígeno específico, e desse modo eliminá-lo mais rápido do organismo. Porém nos pacientes com LES, essa hipermutação somática acarreta no aumento de linfócitos B autorreativos, pois esses indivíduos têm falhas na tolerância imunológica, ${ }^{(54)}$ podendo justificar o aumento dos linfócitos $B$ derivados do centro germinativo nos pacientes em relação aos indivíduos saudáveis.

Além da hipermutação somática nos centros germinativos, ocorre também a diferenciação de linfócitos B em linfócitos de memória, onde podem se proliferar, ou se diferenciar em células secretoras de anticorpos, conhecidas como células plasmáticas. ${ }^{(55,56)}$ Essas informações corroboram com os nossos achados da correlação positiva entre os linfócitos $B$ de memória (CD27 $\lg \mathrm{D}^{-}$) e linfócitos $\mathrm{B}$ derivados do centro germinativo $\left(\mathrm{CD} 8^{+} \lg \mathrm{D}^{-}\right)$durante a fase ativa da doença. Nós pudemos identificar que há uma frequência aumentada de linfócitos provenientes de centros germinativos, sugerindo que são linfócitos ativados e a frequência de linfócitos de memória encontra-se reduzida. Porém quando os pacientes estão em baixa atividade do LES, nós podemos observar a inversão dos resultados citados acima, onde se pode observar que esses indivíduos passam a ter mais linfócitos de memória e menos linfócitos ativos, podendo caracterizar a baixa atividade da doença.

Cappione et al. publicaram um estudo mostrando que os pacientes com LES são falhos ao eliminar linfócitos autorreativos dos centros germinativos. Os dados desse grupo mostra que os linfócitos $B$ derivados do centro germinativo (CD38 ${ }^{+}$ lgD) possuem um perfil autorreativo caracterizado pela presença da molécula 9G4, molécula esta que não foi encontrada em tonsilas de indivíduos saudáveis. ${ }^{(57)}$ Este dado pode complementar o nosso achado de correlação negativa entre a expressão de IgM e linfócitos $\mathrm{B}$ derivados do centro germinativo durante a fase ativa da doença, onde é possível observar que os indivíduos possuíam maior expressão de IgM, que poderia ser justificado por linfócitos B autorreativos. Embora as hipermutações somáticas estejam mais associadas ao lgG, Pascual et al., mostraram que isso também ocorre em IgM, embora sejam menos vistas. ${ }^{(53)}$ 
Houve diminuição na frequência de linfócitos B Naives das pacientes com LES ativo e em baixa atividade quando comparado aos indivíduos saudáveis. Chang et al. realizaram um estudo onde esses linfócitos se apresentam mais ativos nos pacientes com LES. Ele ressalta o papel dessas células como precursoras de linfócitos do GC, linfócitos B de memória e plasmócitos, mas o dado mais importante desse estudo foi a constatação que os linfócitos B Naives estão mais ativos nessa doença. $O$ grupo relaciona a ativação desses linfócitos com a expansão de linfócitos $B$ autorreativos, além da ativação dos linfócitos B Naives através de autoanticorpos ${ }^{(58)}$ e Odendahl et al., sugerem que a relação de diminuição de linfócitos B Naives pode estar relacionado ao aumento de linfócitos $B$ de memória. ${ }^{(59)}$ Com isso, podemos sugerir que a diminuição de linfócitos $\mathrm{B}$ Naives nas participantes desse estudo, está relacionada à provável ativação causada por autoanticorpos, ou pode estar ocorrendo maior diferenciação desses linfócitos em consequência do LES.

O aumento da subpopulação de linfócitos B de memória (CD19+ CD27 lgD`) em pacientes com LES está associado a presença autoanticorpos e também a nefrite lúpica. ${ }^{(52)} \mathrm{E}$ a presença de autoanticorpos faz com que ocorra a diminuição da subpopulação de linfócitos B Pre-switch memory $\left(\mathrm{CD} 19^{+} \mathrm{CD} 7^{+} \operatorname{lgD}{ }^{+}\right.$) em pacientes com LES, sugerindo ser uma particularidade do LES. ${ }^{(60)}$ Esses dois perfis são vistos também em nossa população, onde os linfócitos $B$ de memória das pacientes de LES na V1 e na V2 estão aumentados em relação aos indivíduos saudáveis, já a subpopulação Pre-switch memory das pacientes com LES ativo está diminuída em relação aos indivíduos saudáveis. Uma limitação do nosso estudo foi a falta de maiores dados clínicos para podermos fazer melhor correlação dos achados neste estudo, e a expressão de autoanticorpos na nossa população foi heterogênea (Suplementar 1 e 2), nos impossibilitando de fazer correlações com este dado.

Em nossos resultados, observamos a diminuição dos linfócitos $B$ Intermediate memory de pacientes com LES ativo e em baixa atividade em relação ao grupo de indivíduos saudáveis. Essa subpopulação expressa CD21 em sua superfície, esta proteína é conhecida também como receptor de complemento tipo 2. O CD21 e CD19 juntos, tem função de co-receptores de BCR, e uma vez que há ativação desses co-receptores, ele fará com que haja potencialização do sinal que será recebido pelo BCR, aprimorando a ativação do linfócito $B .{ }^{(61,62)}$ Wehr et al. ainda sugerem que os linfócitos que expressam o CD21 $1^{\text {-llow }}$ também podem expressar marcadores que migram para órgãos e tecidos que estejam em processo inflamatório em pacientes com 
LES. ${ }^{(63)}$ Podemos sugerir que a diminuição desses linfócitos em nossa população portadora de LES se justifica pela possibilidade de migração desses linfócitos para sítios inflamatórios e/ou pela própria característica dos nossos pacientes, pois o mesmo trabalho mostrou que há aumento da frequência desses linfócitos em pacientes com LES, quando são comparados com outras doenças autoimunes, por exemplo, artrite reumatoide $(A R)$ e indivíduos saudáveis. ${ }^{(63)}$

A subpopulação de linfócitos B Tissue-like memory está aumentada nos pacientes com LES em relação aos indivíduos saudáveis em nosso trabalho. Essa subpopulação de linfócitos B tem sido descrita por alguns grupos como células que estão presentes em patologias de características crônicas relacionadas à ativação do sistema imune ou inflamação. ${ }^{(61,64)}$ Desse modo, podemos considerar que o perfil de linfócitos B Tissue-like memory apresentado pelas pacientes com LES ativo e em baixa atividade, condiz com as características descritas na literatura, uma vez que o LES é uma patologia caracterizada por inflamação sistêmica e crônica.

É evidente que o sistema imunológico está em desequilíbrio quando observamos a presença de autoanticorpos e a diminuição significativa de complemento nos pacientes com LES. Por razões como esta, ligadas à resposta imune do LES, que nós acreditávamos que mecanismos de interação celular podem estar relacionados à ativação de linfócitos $B$, e que esta interação poderia ser com células ILC2.

As ILC2 foram descritas em algumas patologias que se assemelham aos LES, uma delas é a ES, doença autoimune multissistêmica, que se caracteriza pela hiperatividade de fibroblastos, acarretando problemas relacionados ao aumento de tecido fibroso disseminado. Wohlfahrt et al. publicaram um estudo com pacientes portadores de ES, onde eles descrevem que a frequência das ILC2 está aumentada tanto no sangue, quanto no tecido cutâneo de pacientes com ES em relação aos indivíduos saudáveis. O grupo também ressalta que as ILC2 presentes na pele desses pacientes expressam de forma homogênea o receptor de linfopoetina estromal tímica (TSLP-R) e o receptor de IL-17b (IL-17RB), demonstrando que essas células estão ativas. $^{(43)}$

Outra doença em que as ILC2 foram descritas foi a AR, assim como o LES é uma doença caracterizada por inflamação crônica, porém localizada nas regiões de articulação, por exemplo, mãos e joelhos. Nas articulações afetadas pela doença há infiltração de leucócitos, e assim inicia-se o processo inflamatório local, a longo prazo e sem o tratamento correto, pode ocorrer destruição do tecido cartilaginoso 
e desgaste ósseo. Rauber et al. descrevem que a frequência das ILC2 no sangue está diminuída durante a atividade da $A R$, mas que após o tratamento a frequência das células aumentam. Quando realizam biópsia do liquido sinovial, o grupo descreve a presença de uma ILC2-like ( $\operatorname{Lin}^{-} \mathrm{ICOS}^{+} \mathrm{IL}-9^{+}$), e da mesma forma que no sangue, essas células estão diminuídas durante a fase ativa, e aumentam durante a baixa atividade da doença. $^{(65)}$

Porém nossos resultados não demonstraram participação das ILC2 na patogênese do LES, o perfil dessas células se manteve igual independentemente da situação da doença ou comparado aos indivíduos saudáveis. O teste funcional das ILC2 também não nos mostrou resultados significantes em relação à doença ativa e em baixa atividade, a produção de citocinas IL-4 e IL-13 não foram diferentes entre os dois grupos.

Uma limitação do nosso estudo, foi a impossibilidade de realizar o experimento de co-cultura de linfócitos B e ILC2, durante a técnica de sorting observamos que as ILC2 não se mantinham vivas para podermos prosseguir com o experimento. Outra intercorrência durante o nosso trabalho foi a dificuldade em realizar experimento funcional com os linfócitos $B$, durante as tentativas de estímulo com PMA e lonomicina, os linfócitos $B$ das pacientes com LES morriam, tentamos modificar o estímulo utilizando anti-CD3 e anti-CD28, mas as células não se mantiveram vivas para analisarmos o perfil funcional. 


\section{CONCLUSÕES}

1. Podemos concluir então que as células linfoides inatas tipo 2 dos pacientes com lúpus eritematoso sistêmico não apresentam diferenças fenotípicas ou funcionais independentemente do estado da doença ou quando comparadas às células linfoides inatas tipo 2 de indivíduos saudáveis, sugerindo que essas células não participam da patogênese do lúpus eritematoso sistêmico.

2. Os pacientes de lúpus eritematoso sistêmico possuem perfis de linfócitos B equivalentes durante atividade e baixa atividade da patologia, e alguns subgrupos podem ser característicos do lúpus eritematoso sistêmico quando comparados com indivíduos saudáveis, como o aumento das subpopulações de linfócitos B do centro germinativo, linfócitos B de memória e linfócitos B Tissue-like memory, e diminuição dos linfócitos B Intermediate memory, linfócitos B Pre-switch memory e linfócitos B Naives, nos pacientes com lúpus eritematoso sistêmico quando comparado aos indivíduos saudáveis. Durante a fase ativa da doença, as pacientes de lúpus eritematoso sistêmico apresentam maior frequência de linfócitos $B$ derivados do centro germinativo em relação aos linfócitos $B$ de memória, dado que caracteriza aumento de linfócitos ativos nesses indivíduos, esse achado sugere que os linfócitos B do centro germinativo pode ser um biomarcador de atividade do Lúpus Eritematoso Sistêmico. Além de apresentarem maior expressão de lgM, que caracteriza linfócitos B autorreativos. Já na fase de baixa atividade da doença, podemos observar que esta correlação se inverte, e os pacientes apresentam maior frequência de linfócitos $B$ de memória em relação aos linfócitos $B$ do centro germinativo, que caracteriza inatividade da doença. 
6 ANEXOS

Anexo 1. Tabela completa do critério de classificação da Systemic Lupus International Collaborating Clinics

\section{Clinical and Immunologic Criteria Used in the SLICC Classification Criteria \\ Clinical Criteria}

1. Acute cutaneous lupus

including lupus malar rash (do not count if malar discoid)

bullous lupus

toxic epidermal necrolysis variant of SLE

maculopapular lupus rash

photosensitive lupus rash

or subacute cutaneous lupus

in the absence of dermatomyositis

(nonindurated psoriaform and/or annular polycyclic lesions that resolve without scarring,

although occasionally with

postinflammatory dyspigmentation or telangiectasias)

2. Chronic cutaneous

lúpus including classical discoid rash localized (above the neck)

generalized (above and below the neck)

hypertrophic (verrucous) lupus

lupus panniculitis (profundus)

mucosal lupus

lupus erythematosus tumidus

chillblains lupus

discoid lupus/lichen planus overlap

3. Oral ulcers: palate

buccal

tongue

or nasal ulcers

in the absence of other causes, such as vasculitis, Behcets, infection (herpes), inflammatory bowel disease, reactive arthritis, and acidic foods

4. Nonscarring alopecia (diffuse thinning or hair fragility with visible broken hairs)

in the absence of other causes such as alopecia areata, drugs, iron deficiency and androgenic alopecia

5. Synovitis involving two or more joints, characterized by swelling or effusion OR tenderness in 2 or more joints and thirty minutes or more of

morning stiffness.

6. Serositis

typical pleurisy for more than 1 day

or pleural effusions

or pleural rub

typical pericardial pain (pain with recumbency improved by sitting forward) for more than 1 day

or pericardial effusion

or pericardial rub

or pericarditis by EKG

in the absence of other causes, such as infection, uremia, and Dressler's pericarditis 
...continuação

7. Renal

Urine protein/creatinine (or $24 \mathrm{hr}$ urine protein) representing $500 \mathrm{mg}$ of protein/24 hr

\section{Clinical Criteria}

or

Red blood cell casts

8. Neurologic

seizures

psychosis

mononeuritis multiplex

in the absence of other known causes such as primary vasculitis

myelitis

peripheral or cranial neuropathy

in the absence of other known causes such as primary vasculitis, infection, and diabetes mellitus

acute confusional state

in the absence of other causes, including toxic-metabolic, uremia, drugs

9. Hemolytic anemia

10. Leukopenia ( $<4000 / \mathrm{mm}^{3}$ at least once)

in the absence of other known causes such as Felty's, drugs, and portal hypertension OR

Lymphopenia (<1000/mm3 at least once)

in the absence of other known causes such as corticosteroids, drugs and infection

11. Thrombocytopenia $(<100,000 / \mathrm{mm} 3)$ at least once

in the absence of other known causes such as drugs, portal hypertension, and TTP

\section{Immunological Criteria}

1. ANA above laboratory reference range

2. Anti-dsDNA above laboratory reference range, except ELISA: twice above laboratory reference range

3. Anti-Sm

4. Antiphospholipid antibody: any of the following

lupus anticoagulant

false-positive RPR

medium or high titer anticardiolipin $(\lg \mathrm{A}, \lg \mathrm{G}$ or $\lg \mathrm{M})$

anti- $\beta 2$ glycoprotein I $(\lg A$, $\lg G$ or $\lg M)$

5. Low complement

low C3

low $\mathrm{C} 4$

low $\mathrm{CH} 50$

6. Direct Coombs test in the absence of hemolytic anemia

Criteria are cumulative and need not be present concurrently.

Fonte: Petri M, Orbai AM, Alarcón GS, Gordon C, Merrill JT, Fortin PR, et al. Derivation and validation of the Systemic Lupus International Collaborating Clinics classification criteria for systemic lupus erythematosus. Arthritis Rheum. 2012;64(8):2677-86 ${ }^{(17)}$ 


\section{REFERÊNCIAS}

1. Rahman A, Isenberg DA. Systemic lupus erythematosus. N Engl J Med. 2008;358(9):929-39.

2. Scofield $\mathrm{RH}$, Oates $\mathrm{J}$. The place of William Osler in the description of systemic lupus erythematosus. Am J Med Sci. 2009;338(5):409-12.

3. Smith CD, Cyr M. The history of lupus erythematosus. From Hippocrates to Osler. Rheum Dis Clin North Am. 1988;14(1):1-14.

4. National Institute of Arthritis and Musculoskeletal and Skin Diseases. Systemic lupus erythematosus (Lupus) [Internet]. Bethesda: National Institutes of Health; c2016. Available from: https://www.niams.nih.gov/health_info/Lupus/default.asp

5. Adinolfi A, Valentini E, Calabresi E, Tesei G, Signorini V, Barsotti S, et al. One year in review 2016: systemic lupus erythematosus. Clin Exp Rheumatol. 2016;34(4):569-74.

6. Tan EM, Cohen AS, Fries JF, Masi AT, McShane DJ, Rothfield NF, et al. The 1982 revised criteria for the classification of systemic lupus erythematosus. Arthritis Rheum.

1982;25(11):1271-7.

7. Carter EE, Barr SG, Clarke AE. The global burden of SLE: prevalence, health disparities and socioeconomic impact. Nat Rev Rheumatol. 2016;12(10):605-20.

8. Miller FW, Alfredsson L, Costenbader KH, Kamen DL, Nelson LM, Norris JM, et al.

Epidemiology of environmental exposures and human autoimmune diseases: findings from a National Institute of Environmental Health Sciences Expert Panel Workshop. J Autoimmun. 2012;39(4):259-71.

9. Cooper GS, Wither J, Bernatsky S, Claudio JO, Clarke A, Rioux JD, et al. Occupational and environmental exposures and risk of systemic lupus erythematosus: silica, sunlight, solvents. Rheumatology (Oxford). 2010;49(11):2172-80.

10. Chong WP, Ip WK, Wong WH, Lau CS, Chan TM, Lau YL. Association of interleukin-10 promoter polymorphisms with systemic lupus erythematosus. Genes Immun. 2004;5(6):484-92.

11. Prokunina L, Castillejo-López C, Oberg F, Gunnarsson I, Berg L, Magnusson V, et al. A regulatory polymorphism in PDCD1 is associated with susceptibility to systemic lupus erythematosus in humans. Nat Genet. 2002;32(4):666-9.

12. Addobbati C, Brandão LA, Guimarães RL, Pancotto JA, Donadi EA, Crovella S, et al. FYB gene polymorphisms are associated with susceptibility for systemic lupus erythemathosus (SLE). Hum Immunol. 2013;74(8):1009-14.

13. Castillejo-López C, Delgado-Vega AM, Wojcik J, Kozyrev SV, Thavathiru E, Wu YY, et al. Genetic and physical interaction of the B-cell systemic lupus erythematosus-associated genes BANK1 and BLK. Ann Rheum Dis. 2012;71(1):136-42.

14. Botto M, Dell'Agnola C, Bygrave AE, Thompson EM, Cook HT, Petry F, et al. Homozygous $\mathrm{C} 1 \mathrm{q}$ deficiency causes glomerulonephritis associated with multiple apoptotic bodies. Nat Genet. 1998;19(1):56-9.

15. Botto M, Walport MJ. C1q, autoimmunity and apoptosis. Immunobiology. 2002;205(45):395-406. 
16. Tan EM, Fritzler MJ, McDougal JS, McDuffie FC, Nakamura RM, Reichlin M, et al. Reference sera for antinuclear antibodies. I. Antibodies to native DNA, Sm, nuclear RNP, and SS-B/La. Arthritis Rheum. 1982;25(8):1003-5.

17. Petri M, Orbai AM, Alarcón GS, Gordon C, Merrill JT, Fortin PR, et al. Derivation and validation of the Systemic Lupus International Collaborating Clinics classification criteria for systemic lupus erythematosus. Arthritis Rheum. 2012;64(8):2677-86.

18. Kao AH, Manzi S, Ramsey-Goldman R. Review of ACR hematologic criteria in systemic lupus erythematosus. Lupus. 2004;13(11):865-8.

19. American College of Rheumatology. Criteria [Internet]. 2018 [cited 2018 Apr 1]. Available from: https://www.rheumatology.org/Practice-Quality/Clinical-Support/Criteria

20. Kuhn A, Bonsmann G, Anders HJ, Herzer P, Tenbrock K, Schneider M. The Diagnosis and Treatment of Systemic Lupus Erythematosus. Dtsch Arztebl Int. 2015;112(25):423-32.

21. Borba EF, Latorre LC, Brenol JC, Kayser C, Silva NA, Zimmermann AF, et al. [Consensus of systemic lupus erythematosus]. Rev Bras Reumatol. 2008;48(4):196-207. Portuguese.

22. Bertsias G, loannidis JP, Boletis J, Bombardieri S, Cervera R, Dostal C, et al.; Task Force of the EULAR Standing Committee for International Clinical Studies Including Therapeutics. EULAR recommendations for the management of systemic lupus erythematosus. Report of a Task Force of the EULAR Standing Committee for International Clinical Studies Including Therapeutics. Ann Rheum Dis. 2008;67(2):195-205.

23. Souza AW, Mesquita Júnior D, Araújo JA, Catelan TT, Cruvinel WM, Andrade LE, et al. Immune system: part III. The delicate balance of the immune system between tolerance and autoimmunity. Rev Bras Reumatol. 2010;50(6):665-79.

24. Stohl W. Inhibition of B cell activating factor (BAFF) in the management of systemic lupus erythematosus (SLE). Expert Rev Clin Immunol. 2017;13(6):623-33.

25. Srivastava A. Belimumab in systemic lupus erythematosus. Indian J Dermatol. 2016;61(5):550-3.

26. Zharkova O, Celhar T, Cravens PD, Satterthwaite AB, Fairhurst AM, Davis LS. Pathways leading to an immunological disease: systemic lupus erythematosus. Rheumatology (Oxford). 2017;56(suppl_1):i55-i66.

27. Abbas AK, Lichtman AH, Pillai S. Cellular and molecular immunology. 8th ed. Philadelphia: Elsevier; 2015.

28. Moir S, Fauci AS. B-cell responses to HIV infection. Immunol Rev. 2017;275(1):33-48.

29. Odendahl M, Jacobi A, Hansen A, Feist E, Hiepe F, Burmester GR, et al. Disturbed peripheral B lymphocyte homeostasis in systemic lupus erythematosus. J Immunol. 2000;165(10):5970-9.

30. LeBien TW, Tedder TF. B lymphocytes: how they develop and function. Blood. 2008;112(5):1570-80.

31. Weisel F, Shlomchik M. Memory B cells of mice and humans. Annu Rev Immunol. 2017;35:255-84.

32. Ellebedy AH, Jackson KJ, Kissick HT, Nakaya HI, Davis CW, Roskin KM, et al. Defining antigen-specific plasmablast and memory $B$ cell subsets in human blood after viral infection or vaccination. Nat Immunol. 2016;17(10):1226-34. 
33. Odendahl M, Mei H, Hoyer BF, Jacobi AM, Hansen A, Muehlinghaus G, et al. Generation of migratory antigen-specific plasma blasts and mobilization of resident plasma cells in a secondary immune response. Blood. 2005;105(4):1614-21.

34. Yanaba K, Bouaziz JD, Matsushita T, Magro CM, St Clair EW, Tedder TF. B-lymphocyte contributions to human autoimmune disease. Immunol Rev. 2008;223:284-99.

35. Yurasov S, Tiller T, Tsuiji M, Velinzon K, Pascual V, Wardemann H, et al. Persistent expression of autoantibodies in SLE patients in remission. J Exp Med. 2006;203(10):2255-61.

36. Shlomchik MJ, Madaio MP, Ni D, Trounstein M, Huszar D. The role of B cells in Ipr/lprinduced autoimmunity. J Exp Med. 1994;180(4):1295-306.

37. Bourne T, Zukowska-Cooper M, Salaman MR, Seifert MH, Isenberg DA. Spontaneous immunoglobulin-producing capacity of cultures from lupus patients and normal donors following depletion of cells expressing CD19 or CD38. Clin Exp Immunol. 1998;111(3):611-6.

38. Schwab J, Lukowsky A, Volk HD, Peter HH, Melchers I. Precursor frequencies for DNAspecific $B$ lymphocytes in patients with systemic lupus erythematosus (SLE). Clin Exp Immunol. 1994;96(3):450-7.

39. Walker JA, McKenzie AN. Development and function of group 2 innate lymphoid cells. Curr Opin Immunol. 2013;25(2):148-55.

40. Walker JA, Barlow JL, McKenzie AN. Innate lymphoid cells--how did we miss them? Nat Rev Immunol. 2013;13(2):75-87.

41. Artis D, Spits H. The biology of innate lymphoid cells. Nature. 2015;517(7534):293-301.

42. Spits H, Artis D, Colonna M, Diefenbach A, Di Santo JP, Eberl G, et al. Innate lymphoid cells--a proposal for uniform nomenclature. Nat Rev Immunol. 2013;13(2):145-9.

43. Wohlfahrt T, Usherenko S, Englbrecht M, Dees C, Weber S, Beyer C, et al. Type 2 innate lymphoid cell counts are increased in patients with systemic sclerosis and correlate with the extent of fibrosis. Ann Rheum Dis. 2016;75(3):623-6.

44. Bal SM, Bernink JH, Nagasawa M, Groot J, Shikhagaie MM, Golebski K, et al. IL-1ß, IL-4 and IL-12 control the fate of group 2 innate lymphoid cells in human airway inflammation in the lungs. Nat Immunol. 2016;17(6):636-45.

45. Lovelace $\mathrm{P}$, Maecker HT. Multiparameter intracellular cytokine staining. Methods Mol Biol. 2011;699:165-78.

46. Roederer M. Spectral compensation for flow cytometry: visualization artifacts, limitations, and caveats. Cytometry. 2001;45(3):194-205.

47. Gladman DD, Ibañez D, Urowitz MB. Systemic lupus erythematosus disease activity index 2000. J Rheumatol. 2002;29(2):288-91.

48. Levey AS, Stevens LA, Schmid CH, Zhang YL, Castro AF 3rd, Feldman HI, et al.; CKD-EPI (Chronic Kidney Disease Epidemiology Collaboration). A new equation to estimate glomerular filtration rate. Ann Intern Med. 2009;150(9):604-12.

49. Macedo AC, Isaac L. Systemic lupus erythematosus and deficiencies of early components of the complement classical pathway. Front Immunol. 2016;7:55. 
50. Wouters $\mathrm{CH}$, Diegenant C, Ceuppens JL, Degreef H, Stevens EA. The circulating lymphocyte profiles in patients with discoid lupus erythematosus and systemic lupus erythematosus suggest a pathogenetic relationship. Br J Dermatol. 2004;150(4):693-700.

51. Goodnow CC, Sprent J, Fazekas de St Groth B, Vinuesa CG. Cellular and genetic mechanisms of self tolerance and autoimmunity. Nature. 2005;435(7042):590-7.

52. Anolik JH. B cell biology and dysfunction in SLE. Bull NYU Hosp Jt Dis. 2007;65(3):182-6.

53. Pascual V, Liu YJ, Magalski A, de Bouteiller O, Banchereau J, Capra JD. Analysis of somatic mutation in five B cell subsets of human tonsil. J Exp Med. 1994;180(1):329-39.

54. Kaminski DA, Wei C, Rosenberg AF, Lee FE, Sanz I. Multiparameter flow cytometry and bioanalytics for $B$ cell profiling in systemic lupus erythematosus. Methods Mol Biol. 2012;900:109-34.

55. Good KL, Avery DT, Tangye SG. Resting human memory B cells are intrinsically programmed for enhanced survival and responsiveness to diverse stimuli compared to naive $B$ cells. J Immunol. 2009;182(2):890-901.

56. Tangye SG, Avery DT, Hodgkin PD. A division-linked mechanism for the rapid generation of Ig-secreting cells from human memory B cells. J Immunol. 2003;170(1):261-9.

57. Cappione A 3rd, Anolik JH, Pugh-Bernard A, Barnard J, Dutcher P, Silverman G, et al. Germinal center exclusion of autoreactive $B$ cells is defective in human systemic lupus erythematosus. J Clin Invest. 2005;115(11):3205-16.

58. Chang NH, McKenzie T, Bonventi G, Landolt-Marticorena C, Fortin PR, Gladman D, et al. Expanded population of activated antigen-engaged cells within the naive B cell compartment of patients with systemic lupus erythematosus. J Immunol. 2008;180(2):1276-84.

59. Odendahl M, Keitzer R, Wahn U, Hiepe F, Radbruch A, Dörner T, et al. Perturbations of peripheral $B$ lymphocyte homoeostasis in children with systemic lupus erythematosus. Ann Rheum Dis. 2003;62(9):851-8.

60. Rodríguez-Bayona B, Ramos-Amaya A, Pérez-Venegas JJ, Rodríguez C, Brieva JA. Decreased frequency and activated phenotype of blood CD27 IgD IgM B lymphocytes is a permanent abnormality in systemic lupus erythematosus patients. Arthritis Res Ther. 2010;12(3):R108.

61. Thorarinsdottir K, Camponeschi A, Gjertsson I, Mårtensson IL. CD21 -/low B cells: A Snapshot of a Unique B Cell Subset in Health and Disease. Scand J Immunol. 2015;82(3):25461.

62. Matsumoto AK, Kopicky-Burd J, Carter RH, Tuveson DA, Tedder TF, Fearon DT. Intersection of the complement and immune systems: a signal transduction complex of the $B$ lymphocyte-containing complement receptor type 2 and CD19. J Exp Med. 1991;173(1):55-64.

63. Wehr C, Eibel H, Masilamani M, Illges H, Schlesier M, Peter HH, et al. A new CD21low B cell population in the peripheral blood of patients with SLE. Clin Immunol. 2004;113(2):161-71.

64. Rubtsova K, Rubtsov AV, Cancro MP, Marrack P. Age-associated B cells: a T-betdependent effector with roles in protective and pathogenic immunity. $\mathrm{J}$ Immunol. 2015;195(5):1933-7.

65. Rauber S, Luber M, Weber S, Maul L, Soare A, Wohlfahrt T, et al. Resolution of inflammation by interleukin-9-producing type 2 innate lymphoid cells. Nat Med. 2017;23(8):93844. 


\begin{abstract}
Introduction: Systemic lupus erythematosus is a chronic multisystemic autoimmune disease of unknown etiology. This disease is characterized by predominant production of autoantibodies against non-specific organ directed to different molecules of the nucleus, cytoplasm and cell surface. There are also an immunocomplexes gather, presence of autoreactive lymphocytes and loss of tolerance. These mechanisms are mainly associated with B-lymphocytes, but other cells of the immune system contribute in the pathogenesis of SLE. Type 2 innate lymphoid cells are a heterogeneous group of lymphocyte subpopulations, characterized by the lack of T-cell receptor on its surface, but some functions are overlapped with conventional T-cells. These functions play an important role in the interaction of innate and adaptive immunity in remodeling and tissue development and secrete IL-4 and IL-13. To date no studies approached ILC2 to SLE, therefore, this study hypothesis is that secretion of IL-4 and IL-13 by ILC2 could be related with activation of B-lymphocytes, and differentiate lymphocytes into plasmocytes and, therefore, induce antibodies/autoantibodies production, and SLE activation. Objectives: To analyze phenotypic and functional profile of B-lymphocytes and type 2 innate lymphoid cells in patients with active lupus and after the disease remission. Methods: We collected blood samples from 19 women with systemic lupus erythematosus when the disease was active and after remission. Seven healthy women composed the control group. Peripheral blood mononuclear cells were isolated by using density gradient centrifugation technique. Cells phenotype and functionality were featured using flow cytometry. Results: Participants showed elevated levels of Creactive protein and lower levels of C3 by comparison of active lupus and lupus remission. No differences in ILC2 compared with control group were seen regarding phenotype and functional profile of active lupus or remission. Subpopulations of Blymphocytes were seen in patients with active and remission lupus however, in active SLE patients we found a correlation between germinal center B lymphocytes and memory B lymphocytes. Conclusions: In patients with active lupus, the B-lymphocytes subgroups increased compared with healthy individuals during active SLE. In addition, a higher frequency of autoreactive germinal center B-lymphocytes was observed suggesting that these lymphocytes may be biomarkers of lupus activity. The ILC2 does not participate in lupus pathogenesis.
\end{abstract}


Suplementar 1 - Auto anticorpos em pacientes com Lúpus ativo (V1)

ID Sexo Raça Idade Data V1 SLEDAl Medicamentos Anti-Cromatina Anti-dsDNA RNP/Sm Anti-Ro Anti-La Anti-Jo-1 Anti-Sm FAN (Núcleo)

\begin{tabular}{|c|c|c|c|c|c|c|c|c|c|c|c|c|c|c|}
\hline \#02 & $\mathrm{F}$ & Branca & 40 & $14 / 12 / 15$ & 12 & NA & 167,9 & $>800$ & 179,5 & NR & NR & NR & 156,1 & $+(1 / 2560)$ \\
\hline \#03 & $F$ & Branca & 37 & $13 / 01 / 16$ & 6 & NA & ND & ND & ND & ND & ND & ND & ND & $+(1 / 2560)$ \\
\hline \#07 & $\mathrm{F}$ & Branca & 58 & $03 / 02 / 16$ & 6 & NA & ND & ND & ND & ND & ND & ND & ND & ND \\
\hline \#08 & $\mathrm{F}$ & Parda & 41 & $10 / 02 / 16$ & 9 & NA & 51,3 & NR & 95,4 & NR & NR & NR & 162,5 & $+(1 / 1280)$ \\
\hline \#09 & $\mathrm{F}$ & Branca & 20 & $17 / 02 / 16$ & 8 & NA & NR & NR & NR & NR & NR & NR & NR & NR \\
\hline$\# 10$ & $\mathrm{~F}$ & Branca & 35 & 09/03/16 & 8 & NA & 153,9 & $>800$ & 142,2 & 105,5 & NR & NR & 96,4 & $+(1 / 5120)$ \\
\hline$\# 12$ & $F$ & Branca & 21 & $13 / 04 / 16$ & 15 & NA & 190,4 & $>800$ & ND & NR & NR & NR & NR & $+(1 / 5120)$ \\
\hline \#13 & $F$ & Branca & 25 & $11 / 05 / 16$ & 12 & NA & 136,3 & 613 & NR & 34 & NR & NR & NR & $+(1 / 2560)$ \\
\hline \#14 & $F$ & Branca & 41 & $15 / 06 / 16$ & 10 & NA & 183,7 & 697 & 152,5 & NR & NR & NR & 112,4 & $+(1 / 1280)$ \\
\hline \#15 & $\mathrm{F}$ & Preta & 19 & $23 / 11 / 16$ & 11 & NA & 146 & $>800$ & NR & NR & NR & NR & NR & $+(1 / 2560)$ \\
\hline \#16 & $\mathrm{F}$ & Branca & 22 & 28/11/16 & 7 & NA & 142,8 & $>800$ & NR & NR & NR & NR & NR & $+(1 / 1280)$ \\
\hline \#18 & $\mathrm{F}$ & Parda & 40 & $04 / 01 / 17$ & 7 & NA & 81,9 & 310 & NR & 20,1 & NR & NR & NR & $+(1 / 2560)$ \\
\hline \#19 & $\mathrm{F}$ & Branca & 49 & $11 / 01 / 17$ & 5 & NA & NR & 82 & NR & 91,3 & 87,5 & NR & NR & $+(1 / 1280)$ \\
\hline \#21 & $\mathrm{F}$ & Parda & 44 & $29 / 03 / 17$ & 10 & NA & NR & NR & NR & 153,8 & 111,5 & NR & NR & $+(1 / 2560)$ \\
\hline \#23 & $\mathrm{F}$ & Branca & 24 & $21 / 06 / 17$ & 18 & NA & 112,9 & $>800$ & 176,4 & 115,4 & NR & NR & 130 & $+(1 / 2560)$ \\
\hline \#25 & $\mathrm{F}$ & Parda & 26 & $29 / 06 / 17$ & 13 & NA & 45,5 & 97 & 125,4 & 91,8 & 88,1 & NR & 71,6 & $+(1 / 2560)$ \\
\hline \#26 & $F$ & Branca & 36 & $29 / 06 / 17$ & 6 & NA & 99,4 & 251 & 31,7 & 82,8 & 56,7 & NR & NR & $+(1 / 640)$ \\
\hline \#27 & $F$ & Branca & 36 & 29/06/17 & 20 & NA & 181,4 & 637 & 87,9 & NR & NR & NR & 59,6 & $+(1 / 1280)$ \\
\hline \#29 & $\mathrm{F}$ & Parda & 18 & $17 / 08 / 17$ & 2 & NA & 106 & 400 & 24,6 & NR & NR & NR & 23,6 & $+(1 / 320)$ \\
\hline
\end{tabular}

F: Feminino; V1: primeira visita; dsDNA: DNA dupla fita; RNP/Sm: Anti-Ribonucleoproteína; Ro: Antígeno A relacionado à síndrome de Sjögren; La: Antígeno B relacionado à síndrome de Sjögren; Anti-Sm: anti-Smith; FAN: Fator anti Nuclear. NR: Não Reagente; R: Reagente; NA: Não Aplicável; ND: Não Disponível. 
Suplementar 2 - Auto anticorpos em pacientes com baixa atividade/remissão do Lúpus (V2)

\begin{tabular}{|c|c|c|c|c|c|c|c|c|c|c|c|c|c|c|}
\hline ID & Sexo & Raça & Idade & Data V2 & SLEDAI & Medicamentos & $\begin{array}{c}\text { Anti- } \\
\text { Cromatina }\end{array}$ & $\begin{array}{c}\text { Anti- } \\
\text { dsDNA }\end{array}$ & $\begin{array}{l}\text { RNP/ } \\
\text { Sm }\end{array}$ & $\begin{array}{c}\text { Anti- } \\
\text { Ro }\end{array}$ & $\begin{array}{c}\text { Anti- } \\
\text { La }\end{array}$ & $\begin{array}{l}\text { Anti- } \\
\text { Jo-1 }\end{array}$ & $\begin{array}{l}\text { Anti- } \\
\text { Sm }\end{array}$ & FAN (Núcleo) \\
\hline \#02 & $F$ & Branca & 41 & 06/09/17 & 3 & cyc + pred + hcq & 173,5 & $>800$ & 161 & NR & NR & NR & 96,2 & $+(1 / 5120)$ \\
\hline \#03 & $\mathrm{F}$ & Branca & 38 & 09/11/17 & 2 & $\mathrm{aza}+$ pred $+\mathrm{hcq}$ & 101,4 & 274 & 80,4 & NR & NR & NR & 31,3 & $+(1 / 1280)$ \\
\hline \#07 & $\mathrm{F}$ & Branca & 59 & $13 / 04 / 16$ & 2 & $\mathrm{mtx}+\mathrm{pred}+\mathrm{hcq}$ & 129,1 & 492 & 94,9 & NR & NR & NR & 65,6 & $+(1 / 1280)$ \\
\hline \#08 & $\mathrm{F}$ & Parda & 41 & 07/06/17 & 4 & cyc + pred + hcq & 55,7 & 134 & 69,6 & NR & 23,7 & NR & 59 & $+(1 / 320)$ \\
\hline \#09 & $\mathrm{F}$ & Branca & 20 & 07/06/17 & 0 & $\mathrm{mmf}+\mathrm{hcq}$ & NR & $\mathrm{NR}$ & NR & NR & NR & NR & NR & $+(1 / 80)$ \\
\hline$\# 10$ & $\mathrm{~F}$ & Branca & 35 & $01 / 02 / 17$ & 0 & cyc + pred + hcq & 138,2 & $>800$ & 135,1 & 25,7 & NR & NR & 50,3 & $+(1 / 5120)$ \\
\hline \#12 & $\mathrm{F}$ & Branca & 22 & $07 / 06 / 17$ & 20 & pred + hcq + aza & 114,5 & $>800$ & NR & 22,3 & NR & NR & NR & $+(1 / 5120)$ \\
\hline \#13 & $\mathrm{F}$ & Branca & 27 & $25 / 10 / 17$ & 0 & pred + hcq & 140,7 & $>800$ & 58,5 & 57,6 & NR & NR & 46,7 & $+(1 / 5120)$ \\
\hline \#14 & $\mathrm{F}$ & Branca & 42 & $23 / 11 / 16$ & 0 & cyc + pred + hcq & NR & 119 & 106,1 & NR & NR & 27 & 79,2 & $+(1 / 320)$ \\
\hline \#15 & $\mathrm{F}$ & Preta & 19 & $06 / 07 / 17$ & 4 & cyc + pred + hcq & 108,9 & $>800$ & NR & NR & NR & NR & NR & $+(1 / 5120)$ \\
\hline \#16 & $\mathrm{F}$ & Branca & 23 & $25 / 01 / 18$ & 0 & $\mathrm{aza}+$ pred $+\mathrm{hcq}$ & 117,7 & $>800$ & NR & NR & NR & NR & NR & $+(1 / 5120)$ \\
\hline \#18 & $\mathrm{F}$ & Parda & 42 & 06/06/17 & 1 & pred + hcq & 37,7 & 112 & 51 & NR & NR & NR & NR & $+(1 / 1280)$ \\
\hline \#19 & $\mathrm{F}$ & Branca & 50 & $23 / 11 / 17$ & 0 & pred + hcq & NR & NR & NR & 80,8 & 38,3 & NR & NR & $+(1 / 640)$ \\
\hline \#21 & $\mathrm{F}$ & Parda & 45 & $02 / 11 / 17$ & 8 & aza + pred + hcq & NR & NR & NR & 96,2 & 105,9 & NR & NR & $+(1 / 640)$ \\
\hline \#23 & $F$ & Branca & 24 & $23 / 11 / 17$ & 12 & pred + hcq & 94,7 & 641 & 141,2 & 84,9 & NR & NR & 105,9 & $+(1 / 2560)$ \\
\hline \#25 & $\mathrm{F}$ & Parda & 27 & $22 / 09 / 17$ & 5 & cyc + pred + hcq & $\mathrm{NR}$ & NR & 114 & 128 & 136 & NR & 62,4 & $+(1 / 1280)$ \\
\hline \#26 & $\mathrm{F}$ & Branca & 37 & $26 / 01 / 17$ & 1 & pred + hcq & 59,7 & 304 & ND & ND & ND & ND & ND & $+(1 / 640)$ \\
\hline \#27 & $\mathrm{F}$ & Branca & 37 & $02 / 11 / 17$ & 4 & cyc + pred + hcq & 81,8 & 479 & 73 & NR & NR & NR & 59,6 & $+(1 / 2560)$ \\
\hline \#29 & $\mathrm{F}$ & Parda & 19 & $01 / 02 / 18$ & 0 & $\begin{array}{c}\mathrm{mtx}+\text { aza }+ \text { pred } \\
+\mathrm{hcq}\end{array}$ & 102,9 & 485 & NR & NR & NR & NR & NR & $+(1 / 320)$ \\
\hline
\end{tabular}

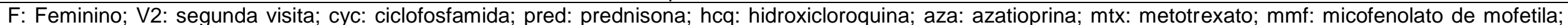

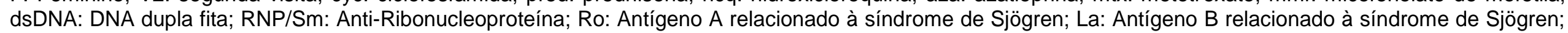
Anti-Sm: anti-Smith; FAN: Fator anti Nuclear. NR: Não Reagente; R: Reagente; NA: Não Aplicável; ND: Não Disponível 